\title{
Antalya Atatürk Kültür Parkı Örneğinde Rekreasyonel Ekosistem Hizmetlerinin Değerlendirilmesi
}

\author{
Zeynep AKBULUT ${ }^{1 *}$, Mehmet TOPAY ${ }^{2}$ \\ ORCID 1: 0000-0001-9801-1506 \\ ORCID 2: 0000-0002-3897-1756 \\ ${ }^{1}$ Süleyman Demirel Üniversitesi, Fen Bilimleri Enstitüsü, Peyzaj Mimarlığı Ana Bilim Dalı, 32260, Isparta, Türkiye. \\ ${ }^{2}$ Süleyman Demirel Üniversitesi, Mimarlık Fakültesi, Peyzaj Mimarlı̆̆ı Bölümü, 32260, Isparta, Türkiye. \\ *e-mail: zeynepakbulut0606@gmail.com \\ Öz \\ Kentsel açık ve yeşil alanların önemli bir bileşeni olan kent parkları, kent insanına ve kent ekosistemine çok yönlü \\ hizmet ve katkılar sağlamaktadır. Bu çalışmanın amacı, Antalya Atatürk Kültür Parkının sağladığı rekreasyonel ve \\ ekosistem hizmetlerine yönelik kullanıcı görüşlerinin belirlenmesidir. Bu kapsamda öncelikle kent parkının mevcut \\ durumu ortaya koyulmuştur. Parktaki rekreasyonel ekosistem hizmeti sağlama potansiyelinin değerlendirilmesi \\ için 400 katılımcıya yüz yüze anket çalışması uygulanmıştır. Anket sonuçlarına göre; görsel çekicilik ve estetiği \\ açısından tercih ettikleri $(\% 18,3)$, en çok yaya gezinti alanlarını kullandıkları $(\% 17,6)$ ve temiz hava almak ve \\ stresten uzaklaşmak $(\% 25,5)$ amacı ile kullanmakta oldukları belirlenmiştir.
}

Anahtar Kelimeler: Ekosistem hizmetleri, rekreasyon, kent parkı, Atatürk Kültür Parkı.

\section{Evaluation of Recreational Ecosystem Services in an Example of Antalya Atatürk Cultural Park}

\begin{abstract}
Urban parks, which are an important component of urban open and green spaces, provide versatile services and contributions to the city people and the city ecosystem. The aim of this study is to determine the user opinions regarding the recreational and ecosystem services provided by Antalya Atatürk Culture Park. In this context, the current state of the city park was firstly revealed. In order to evaluate the potential of providing recreational ecosystem service in the park, 400 participants were interviewed face to face. According to the survey results; It was determined that they preferred in terms of visual appeal and aesthetics (18.3\%), they mostly used pedestrian walking areas (17.6\%) and they used them for the purpose of getting fresh air and getting away from stress (25.5\%).
\end{abstract}

Keywords: Ecosystem services, recreation, urban park, Atatürk Culture Park.

Atıf: Akbulut, Z. ve Topay, M. (2020). Antalya Atatürk Kültür Parkı Örneğinde Rekreasyonel Ekosistem Hizmetlerinin Değerlendirilmesi. Mimarlık Bilimleri ve Uygulamaları Dergisi, 5(1), 64-80.

DOI: $10.30785 / \mathrm{mbud} .716595$ 


\section{Giriş}

Kırsaldan kente göçlerin ve nüfusun hızıı artışı yoğun yapılaşmaya neden olmaktadır. Artan yapılaşmadan kaynaklanan, kentlerde yer alan açık ve yeşil alanların azalması ve giderek yok olması kaçınılmaz hale gelmektedir. Açık ve yeşil alanların bir parçası olan kent parkları; kentteki yapılaşmayı sınırlandırma, iklimi düzenleme, hava kalitesini arttırma, rekreasyon olanakları sağlama, kent estetiğini zenginleştirme gibi özellikleriyle insan yaşamı ve gereksinimleri açısından birçok işlevi yerine getirmektedir.

Yücel ve Yıldızcı'ya (2006) göre; kent parkları, kentsel yaşam kalitesinin arttırılmasında en önemli etkenlerden birisidir (Yıldııım, Erdoğan ve Oktay, 2014). Bir parkı yaşanabilir ve algılanabilir kılan donatı elemanlarının her biri; park açııından çevreyi tanımlayan, belirleyen ve özelleştiren nitelikleri nedeniyle de vazgeçilmezdir. Bulundukları çevre ile bütünleşerek parkın bir öğesi haline gelen donatı elemanları, park kimliğini oluşturan önemli araçlardandır (Yıldırım, Erdoğan ve Oktay, 2014).

Kent sakinleri; kentte yaşamanın getirdiği sosyal, ekonomik ve psikolojik açıdan olumsuz baskıları üzerlerinde hissederler. Yaşamlarını kendilerine sunulan ortamlarda devam ettirirler. Bina kümeleri, trafik yoğunluğu, kirlilik gibi faktörler kentsel ortamın öğelerindendir. Kentsel dış mekânların, doğru biçimde tasarlanması ve uygulanması, maddi olarak desteklenmesi, idare edilmesi ve bakımlarının yapılması, kentte yaşamanın olumsuz etkilerini azaltmaktadır. Kent parkları; kentte yaşamanın getirdiği olumsuz koşulları iyileştirici etkisiyle, kentsel yaşam kalitesinin artırılmasında önemli bir paya sahiptir. Çağdaş planlama ve tasarımların kentlerin formuna ilişkin temel ilkesi; kent bünyesinde parklar oluşturmak değil, park içerisinde kentler oluşturmak görüşü üzerinde odaklanmıştır (Eşkil, 2011).

Kent parkları; insanları şehir yaşamının stresinden kurtaran ve kendilerine zaman ayırabilecekleri sosyal ve çevresel fonksiyonlarıla hizmet veren kentsel yeşil alanlardır. Bu sebeple, havayı temizlemek, gürültüyü azaltmak, estetik bir görünüş sağlamak ve kirliliği kontrol etmek gibi faydalarıyla kent parklarının ne derece önemli olduğu açıkça görülmektedir (Kahya, 2018).

Jacobs'a (1961) göre insanların parkları aktif rekreasyonel kullanımından ziyade, ziyaret etmelerinin sebeplerinden bazıları; rahatlamak, okumak, farklı bireylerle bilinçli veya kendiliğinden buluşmak, şehrin meşguliyetinden sıyrılmak, doğaya temas etmek, çocukları eğlendirmek, insanları veya sadece ne olduğunu seyretmektir (Ibes Dorothy, 2016). National Recreation and Parks Association'ya (NRPA) (2012) göre kentsel parklarda rekreasyon imkanlarının; park büyüklüğü, kolay ulaşım, kullanım birimlerinin sağlamlığı ve bakımı, güvenlik, estetik, tesisler ve yapılı çevre ile ilgilidir. Parkların büyüklüğü ve yakınlığı; park kullanımının yanı sıra şehir sakinlerinin fiziksel egzersiz yapma sıklığının ve seviyesinin artması ile bağlantılı olduğu gösterilmiştir (Ibes Dorothy, 2016).

NRPA (2012), kent parklarının kent sakinlerine uygun ulaşım yoluyla erişim sağlaması, güvenli olması, çeşitli tercihler için çeşitli kullanım birimleri/faaliyetlerini barındırması gerektiğinin yanı sıra doğal özelliklerini sürdürmesi ve kültürel özelliklerini aktarması gerektiğini belirtmiştir. Kent parklarında yer alan etkinlik ve faaliyetlerin; gençlik gelişiminde sosyal, zihinsel, fiziksel ve duygusal sağlığı olumlu yönde etkisini kolaylaştıracağını savunmuştur (Ibes Dorothy, 2016).

Bu araştırma kapsamında; açık ve yeşil alanların bir parçası olan kent parklarındaki kullanım alanlarının peyzaj tasarım ilkeleri doğrultusunda mevcut durumunun incelenmesi ve kent parklarında olması gereken faaliyetlerinin yeterliliği belirlenerek; Antalya Atatürk Kültür Parkı'nın sağladığı rekreasyonel ekosistem hizmetlerine yönelik kullanıcı görüşlerine dayalı bir değerlendirme yapılmaktadır.

\section{Materyal ve Yöntem}

Çalışmanın ana materyalini Antalya Atatürk Kültür Parkı oluşturmaktadır. Antalya Atatürk Kültür Parkı; Antalya ilinin Muratpaşa ilçesine bağlı Meltem mahallesinde bulunmaktadır. Antalya Atatürk Kültür Parkı'nın doğusunda Tenis ìhtisas Kulübü, batısında merkezinde Dumlupınar Bulvarı, kuzeyinde Sakıp Sabancı Bulvarı ve güneyinde Akdeniz bulunmaktadır (Şekil 1).

Çalışma kapsamında kullanıcılara yönelik yapılacak olan anket formu, literatür taraması sonucu ve uzman görüşler doğrultusunda hazırlanmıştır. Kullanıcılara yönelik yapılan anket çalışmasında; örneklem büyüklüğü Antalya il nüfusu göz önünde bulundurularak belirlenmiştir. Yazıcıoğlu ve 
Erdoğan'ın (2014) hazırlamış olduğu evren büyüklüğüne göre örneklem büyüklüğünün hesaplanmasına yönelik tablodan faydalanılarak nüfusu 1.000.000'un üzerinde olan araştırma alanı için 0.05 anlamlılık düzeyinde $d=+0.05$ örnekleme hatası ile $p=0.5, q=0.5$ olasılığında 384 kullanıcı anketi yapılması gerekmektedir. TÜiK'in Adrese Dayalı Nüfus Kayıt Sistemine göre Antalya'nın 2018 yılı nüfusu 2,426.356'yı göstermektedir (Türkiye İstatistik Kurumu (TÜiK), 2019). Bu verilere dayanarak 400 anket yapılmasına karar verilmiştir.

Anket çalışması gönüllülük ilkesine dayanarak tesadüfi olarak seçilen kullanıcılara; Eylül, Ekim, Kasım ayları boyunca haftanın ve günün farklı zaman dilimlerinde yüz yüze görüşme şeklinde yapılmıştır. Anket çalışmasından elde edilen verilerin değerlendirilmesi; SPSS (IBM SPSS Statistics 20) programı içerisinde yer alan Chi-square testi ve Frekans dağılımı analizleri ile yapılmıştır.

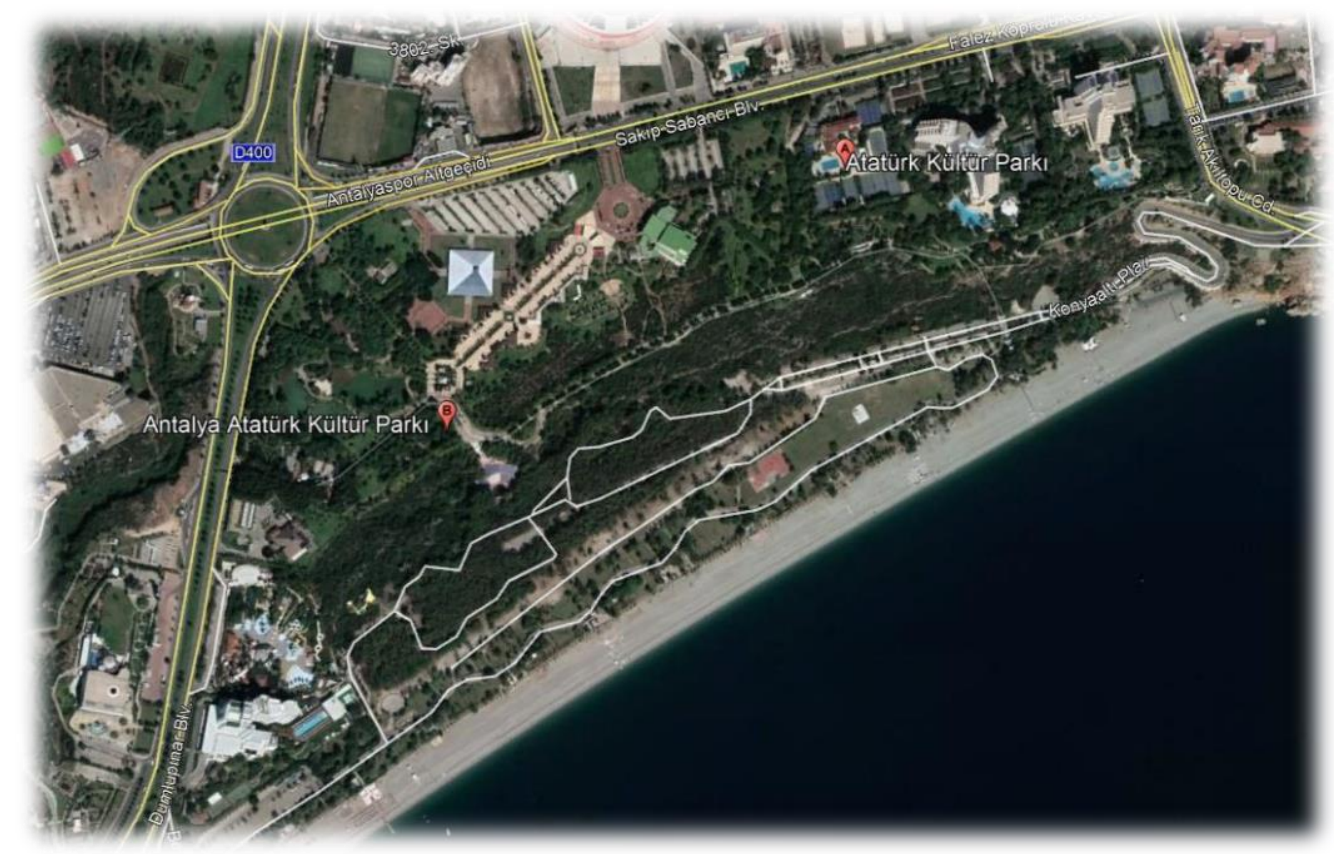

Şekil 1. Antalya Atatürk Kültür Parkı konumu (Google Earth, 2018)

\section{Araştırma Bulguları}

\subsection{Atatürk Kültür Parkı’nın Mevcut Durumu}

Uzun (1987), Özkan (1988) ve Kılıç (1997)'ın yaptıkları çalışmalara göre; kent parklarındaki kullanımlar işlevlerine göre Çizelge 1'de verilmiştir (Polat, 2001; Kahya, 2018). Atatürk Kültür Parkı'nda yapılan yerinde gözlem ve incelemeler doğrultusunda; alanda mevcut olan kullanım birimleri ortaya koyulmuştur (Çizelge 1.). Parktaki kullanım birimlerinin plan görünümü Şekil 2'de verilmiştir. 
Çizelge 1. Atatürk Kültür Parkı'ndaki kullanım birimlerinin mevcut durumu (Kahya, 2018)

\begin{tabular}{|c|c|c|c|}
\hline & & Mevcut & Mevcut değil \\
\hline \multirow{8}{*}{ Rekreasyonel Birimler } & Spor kompleksi & $\mathbf{x}$ & \\
\hline & Yapay göller, büyük su alanları & $\mathbf{x}$ & \\
\hline & Çocuk oyun alanları & $\mathbf{x}$ & \\
\hline & Piknik alanları & $\mathbf{x}$ & \\
\hline & Yaya gezinti alanları & $\mathbf{x}$ & \\
\hline & Oturma yerleri & $\mathbf{x}$ & \\
\hline & Teraslar & & $\mathbf{x}$ \\
\hline & Bisiklet yolları & $\mathbf{x}$ & \\
\hline \multirow{5}{*}{ Bilimsel ve Eğitsel Birimler } & Bilim merkezi & & $\mathbf{x}$ \\
\hline & Botanik bahçesi & & $\mathbf{x}$ \\
\hline & Hayvanat bahçesi & & $\mathbf{x}$ \\
\hline & Tabiat müzesi & & $\mathbf{x}$ \\
\hline & Gözlemevi & & $\mathbf{x}$ \\
\hline \multirow{4}{*}{ Sosyal-kültürel birimler } & Açık hava sergileri & $x$ & \\
\hline & Konser alanları & $\mathbf{x}$ & \\
\hline & Tiyatro alanları & $\mathbf{x}$ & \\
\hline & Fuarlar & $\mathbf{x}$ & \\
\hline \multirow{2}{*}{ İşletme birimleri } & Çay bahçeleri, kafe ve restoranlar & $\mathbf{x}$ & \\
\hline & Fidanlık ve seralar & $\mathbf{x}$ & \\
\hline \multirow{6}{*}{ Hizmet birimleri } & Teknik üniteler & & $\mathbf{x}$ \\
\hline & İdari üniteler & $\mathbf{x}$ & \\
\hline & Acil yardım, Ptt gibi servis hizmetleri & & $\mathbf{x}$ \\
\hline & Bankamatik & & $\mathbf{x}$ \\
\hline & Tuvaletler & $\mathbf{x}$ & \\
\hline & Otoparklar & $\mathbf{x}$ & \\
\hline
\end{tabular}

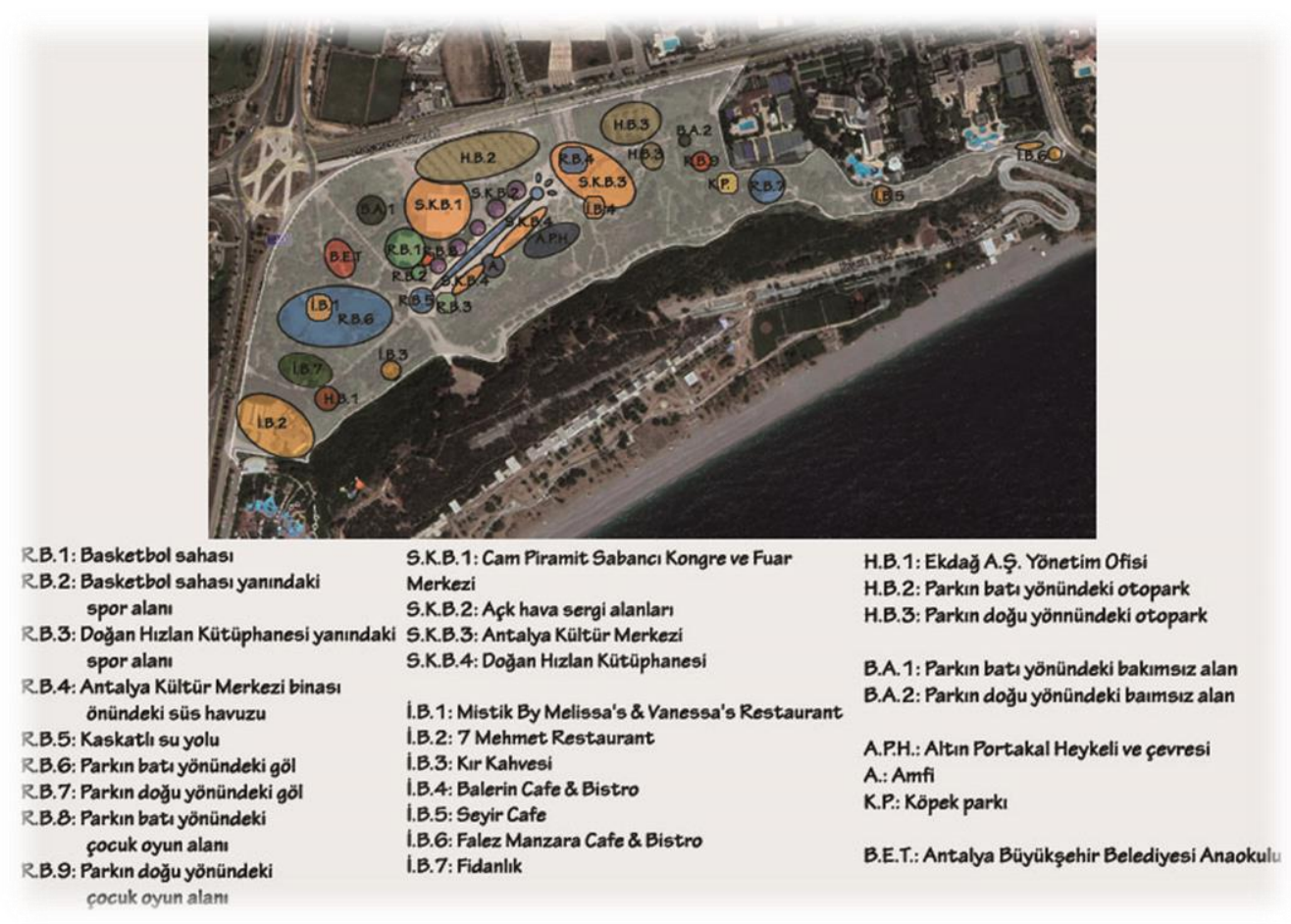

Şekil 2. Atatürk Kültür Parkı'nda bulunan fonksiyonel birimlerin plan görünümü

\subsubsection{Rekreasyonel birimler}

Spor alanları: Antalya Atatürk Kültür Parkı içinde çift potalı üç adet basketbol sahası (1) bulunmaktadır. Bu basketbol sahalarının yanı sıra iki ayrı yerde de kondisyon aletlerinin bulunduğu spor alanları mevcuttur. Kondisyon aletlerinin bulunduğu spor alanlarından ilki (2) basketbol sahalarının yanında bulunmaktadır. Diğer spor alanı (3) ise Doğan Hızlan Kütüphanesi'nin batı yönünde yer almaktadır. Parkta bulunan spor alanları Şekil 3'de verilmektedir. Basketbol sahasının zemin döşemesi kilit parke 
taşı ile döşenmişken diğer spor alanlarının zemini çimdir. Kondisyon aletleri metal malzemelerle ve 12 yaşından büyük kullanıcılara yönelik tasarlanmıştır.
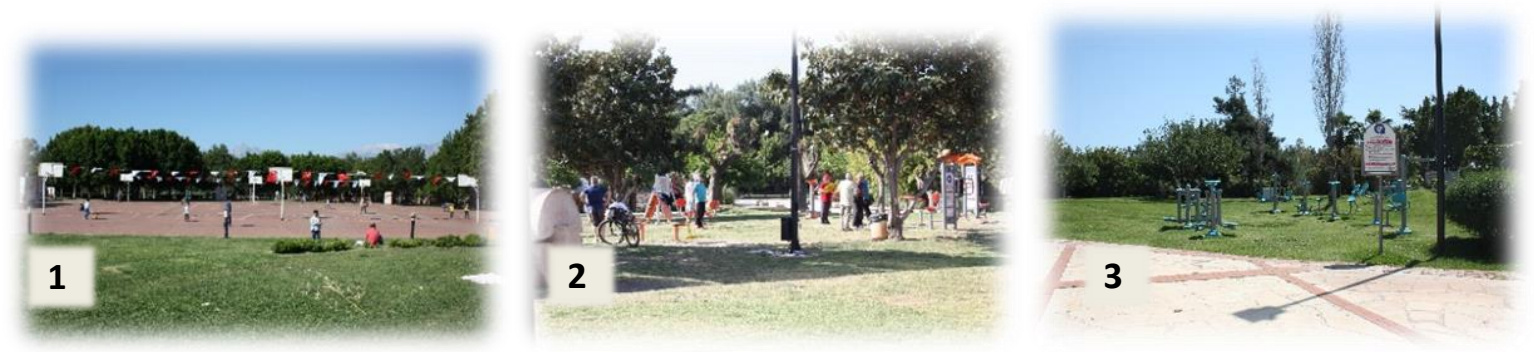

Şekil 3. Atatürk Kültür Parkı'nda bulunan spor alanları

Yapay göller, büyük su alanları: Alan içerisinde iki göl ve iki süs havuzu olmak üzere dört adet su öğesi bulunmaktadır. Bu süs havuzlarından ilki; Antalya Kültür Merkezi binası önünde (1) bulunmaktadır. Bu havuz dairesel olarak tasarlanmış; etrafı ise heykeller ve çeşitli bitkilerle çevrilerek görsel estetiği arttırılmıştır.

Diğer süs havuzu ise; doğrusal çizgiyle, kaskatlı olarak (2) devam etmektedir. Kaskatlı olarak devam eden bu suyolu; yaklaşık 2 metre yükseklikteki bir amfide üç ayrı noktada başlayıp parkın batı tarafında bulunan göl ile birleşmektedir. Amfiden aşağı yöne (parkın batı yönüne) doğru ilerledikçe etrafı su ile çevrili bir meydan görülmektedir. Meydana erişim her iki tarafında bulunan köprülerle sağlanmaktadır. Suyolunun devamı boyunca kuzey ve güney yönlerinde geniş yaya yolları bulunmaktadır. Paralel olarak konumlanan bu yaya yollarına erişim, suyolunun üzerinde bulunan köprüler ile sağlanmaktadır. Kaskatı bir şekilde devam eden suyolu, taş bir piramit görseli ile sona ermekte ve su akışı bu piramidin çevresinden geçerek parkın batı yönündeki göle (3) bağlanmaktadır.

Parkın doğu yönünde bir göl (4) daha bulunmaktadır. Bu göl, kaskatlı bir yapıya sahiptir. Göl üzerinden bir köprü ile doğu yönüne doğru sirkülasyon devam etmektedir. Göl içerisinde bulunan balıklar, çevresinde bulunan bitkiler ve güney yönündeki denizin görüntüsü, insanlar üzerinde doğallık hissini arttırırken alanı estetik açıdan olumlu yönde etkilemektedir. Yapay göller ve büyük su alanlarının görseli Şekil 4'de verilmektedir.
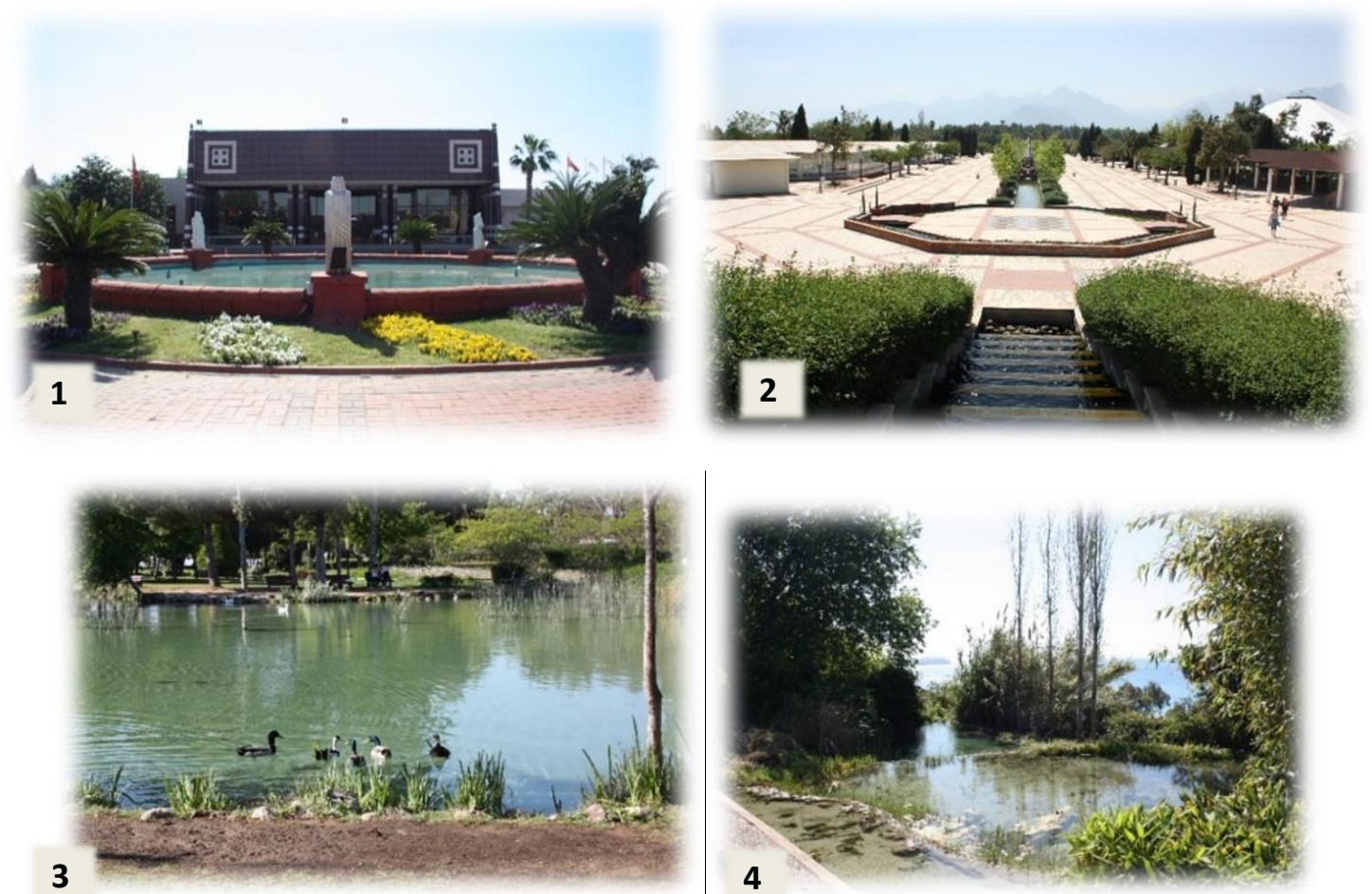

Şekil 4. Atatürk Kültür Parkı'nda bulunan yapay göller, büyük su alanları 
Çocuk oyun alanları: Araştırma alanında; farklı alanlarda konumlanmış iki çocuk oyun alanı bulunmaktadır. Çocuk oyun alanlarından birincisi basketbol sahasının yanında (1), ikincisi ise parkın doğu yönünde (2) bulunmaktadır. Çocuk oyun alanlarının görseli Şekil 5'de verilmektedir. Çocuk oyun alanları metal ve plastik malzemeler ile tasarlanmış, zemin döşemesi kullanılmayarak stabilize şekilde bırakılmıştır.

Piknik alanları: Park bünyesinde piknik alanı olarak nitelendirilen özel bir kullanım birimi bulunmamaktadır. Parkta piknik yapmak yasaktır. Fakat parktaki çim alanlarda, kullanıcılar tarafından birçok yerde piknik yapıldığı gözlemlenmiştir. Bu durumda park ziyaretçileri, parkı piknik yapma amacıyla kullandıklarını ifade etmektedir (Şekil 6).

Bisiklet yolları: Parkın yaya gezinti alanlarının bir kısmı aynı zamanda bisiklet yolu olarak da kullanılmaktadır (Şekil 6). Bisiklet yolları çift yönlü ve zemini mavi renge boyanmış durumdadır.

Yaya gezinti alanları: Parkın yaya gezinti alanları ziyaretçileri, parktaki çeşitli kullanım birimlerine ve farklı manzara noktalarına yönlendirmektedir. Bununla birlikte yürüyüş amacı ile de kullanılmaktadır. Yaya gezinti alanlarının zemin döşeme malzemesi farklılık göstermektedir. Bazı alanlarda asfalt ve stabilize zemin, bazı alanlarda kayrak taşı ve andezit zemin döşemesi kullanıldığı gözlemlenmiştir. Yaya gezinti alanlarına ait örnek görsel Şekil 7'de verilmiştir.

Oturma yerleri: Park bünyesinde bulunan farklı konumlardaki oturma birimlerinin bazıları dinlenme amaçlı bazıları ise manzara noktası niteliği taşıyan alanlarda bulunmaktadır (Şekil 8). Oturma birimlerinin, doğal taş ve ahşap malzemelerle, farklı formlarda tasarlandığı tespit edilmiştir.
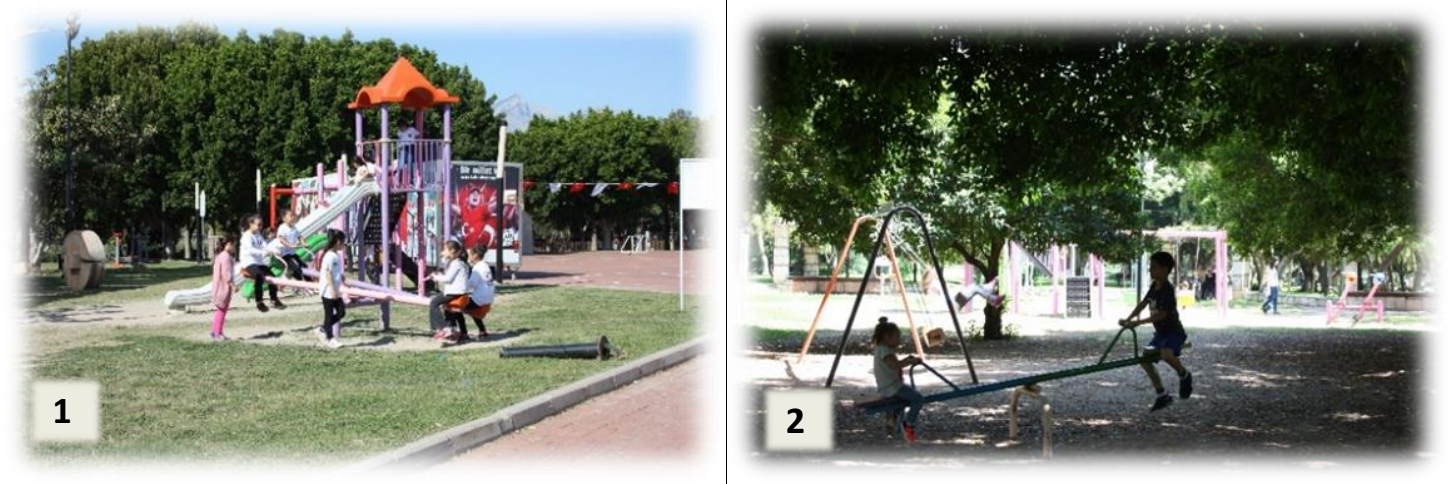

Şekil 5. Atatürk Kültür Parkı'nda bulunan çocuk oyun alanları
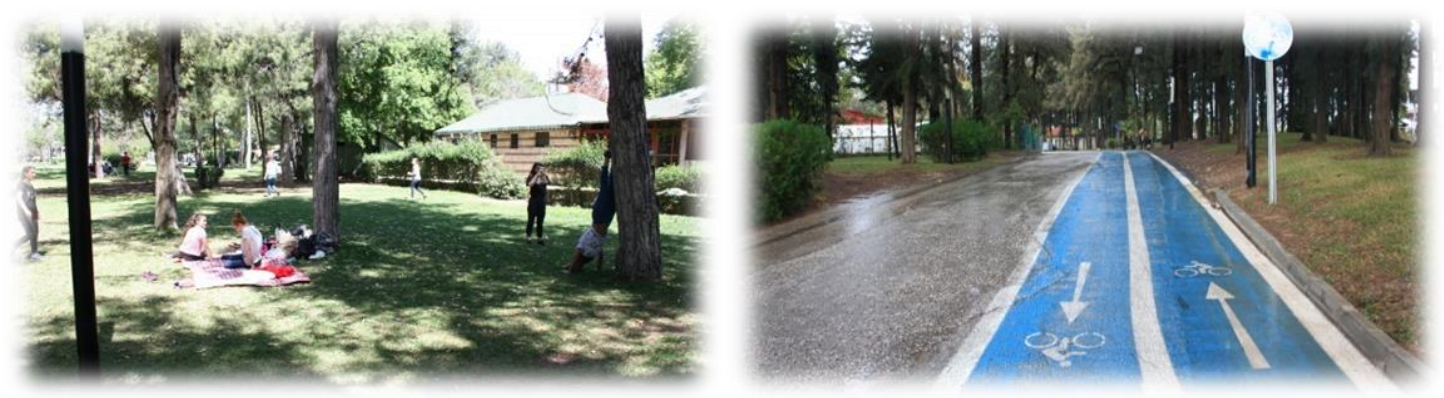

Şekil 6. Parkın; piknik alanı olarak kullanımına örnek görsel ve bisiklet yolları 

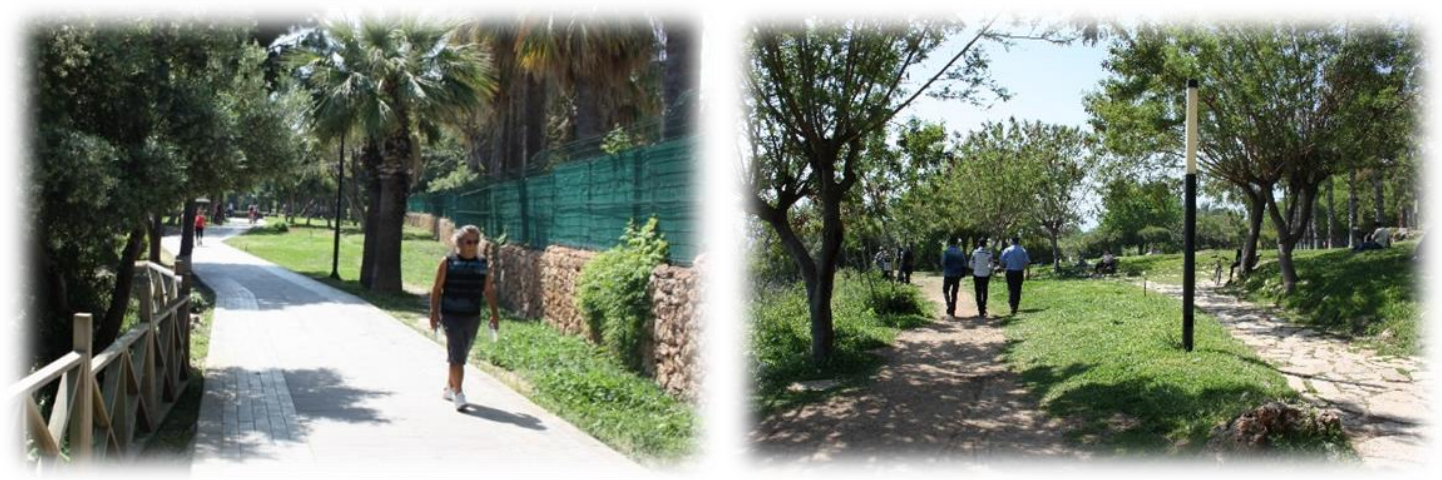

Şekil 7. Parktaki yaya gezinti alanları
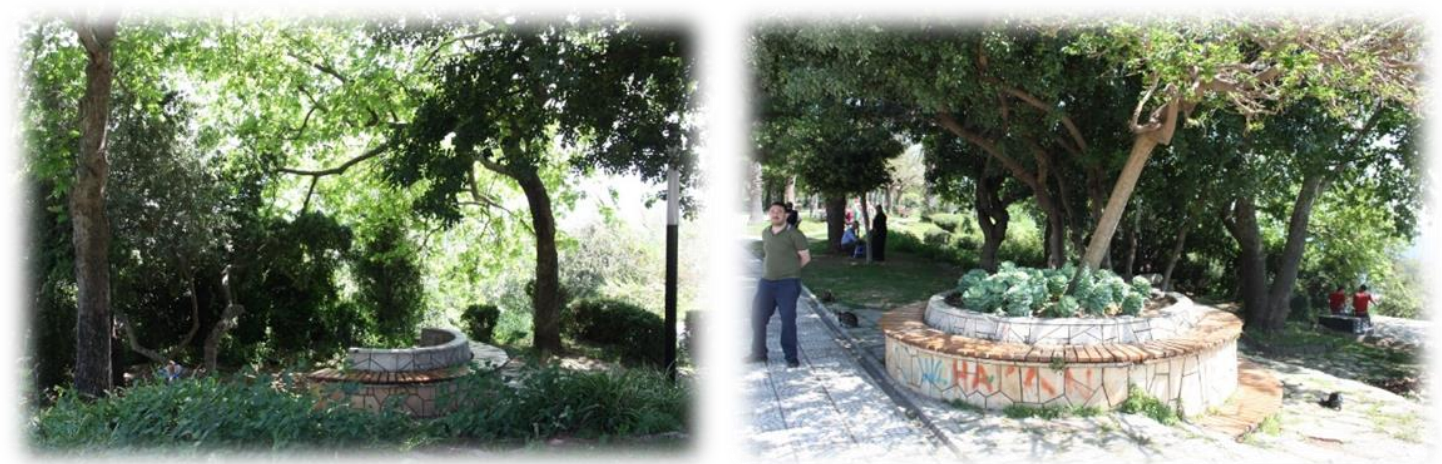

Şekil 8. Parktaki oturma birimleri

\subsubsection{Bilimsel ve eğitsel birimler}

Antalya Atatürk Kültür Parkı bünyesinde bilimsel ve eğitsel birimler başlığı altında bulunan kullanım birimlerinden herhangi biri mevcut değildir. Fakat bu kullanım birimlerin dışında eğitim kurumu olarak Antalya Büyükşehir Belediyesi Anaokulu bulunmaktadır. Okulun görseli Şekil 9'da gösterilmiştir.

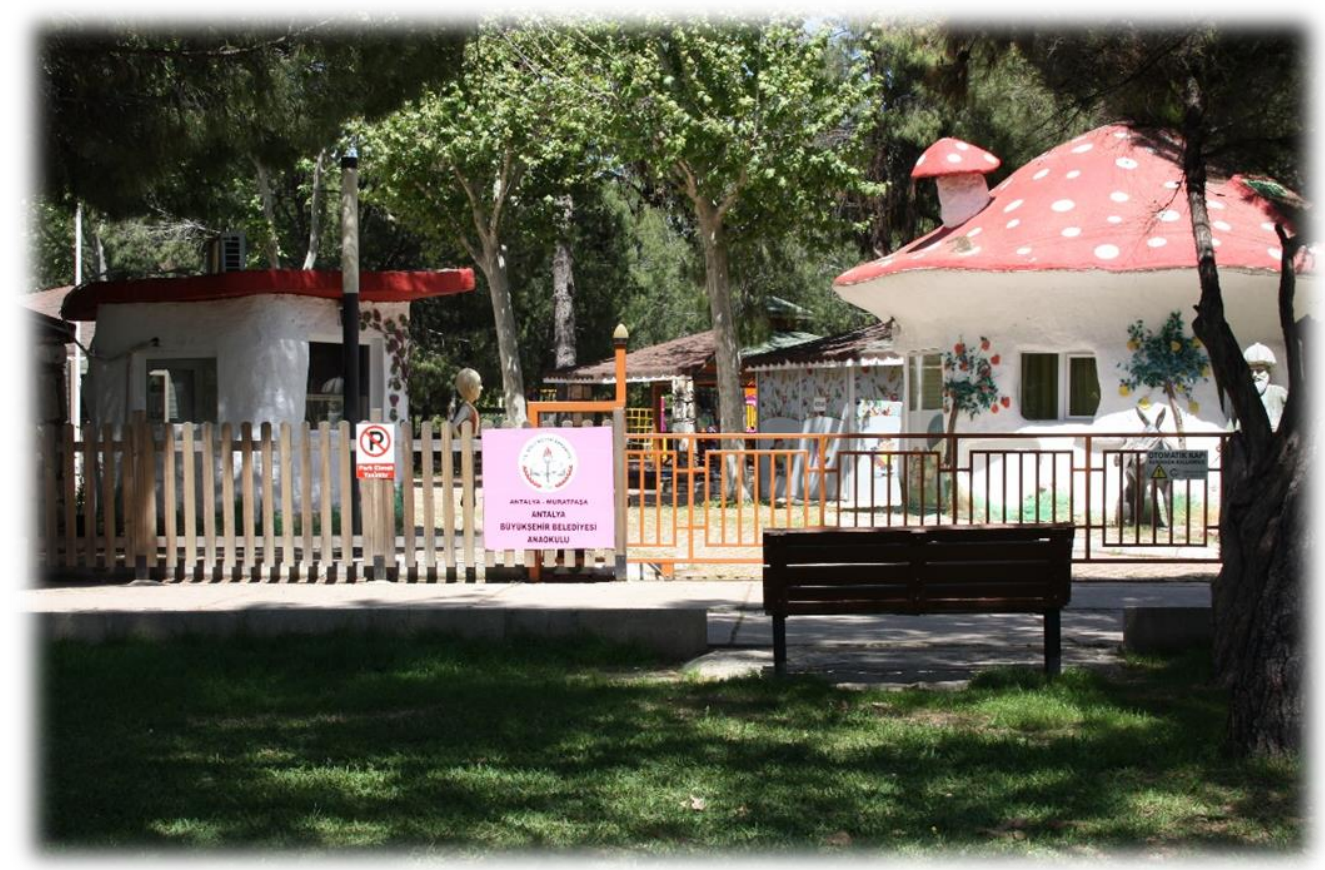

Şekil 9. Atatürk Kültür Parkı'nda bulunan Antalya Büyükşehir Belediyesi Anaokulu

\subsubsection{Sosyal-kültürel birimler}

Araştırma alanında öngörülen sosyal-kültürel birimlerin tümü park bünyesinde mevcuttur (Şekil 10). Park bünyesinde yer alan Cam piramit Sabancı Kongre ve Fuar Merkezi (1) ve çevresinde bulunan açık 
sergi alanlarında (2); çeşitli zamanlarda yöresel gıda vb. fuarlar gibi çeşitli kültürel aktivitelerin sergilendiği tespit edilmiştir. Antalya Kültür Merkezi'nde (3) tiyatro ve konser gösterilerinin yapıldığı görülmüştür. Doğan Hızlan Kütüphanesi (4), farklı zamanlarda yapılan proje yarışmaları ve kitap fuarları gibi etkinliklere ev sahipliği yapmaktadır.

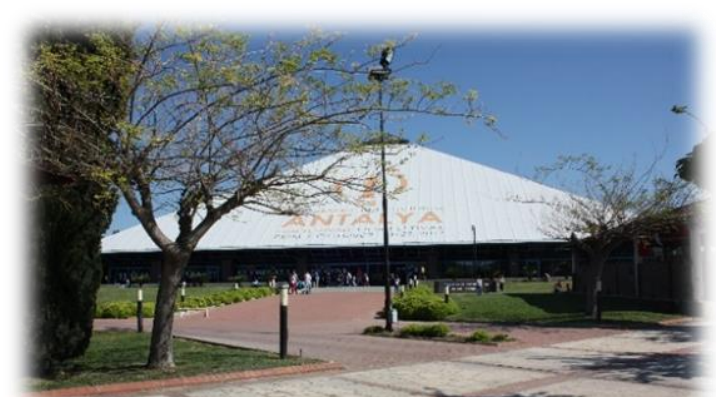

1
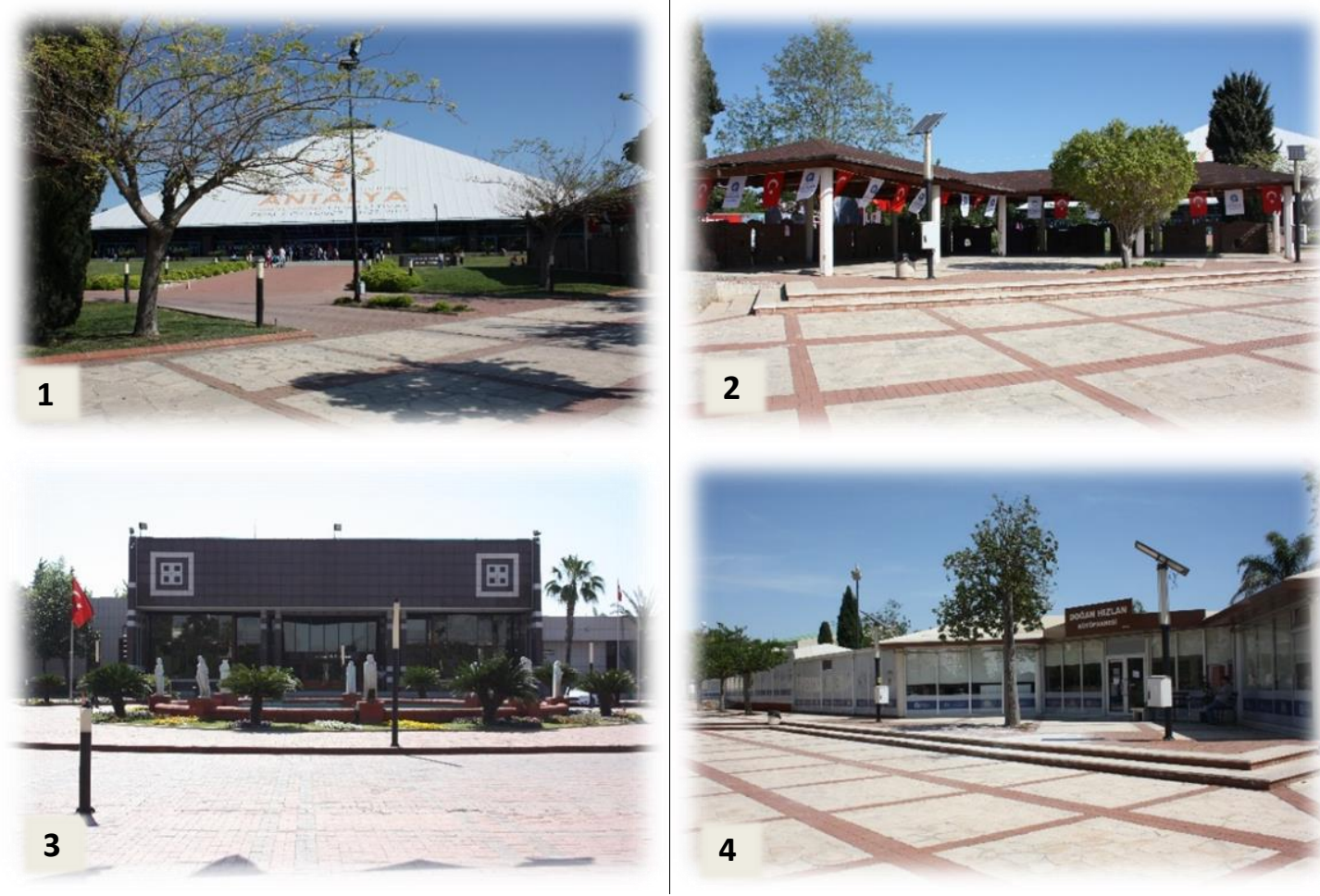

Şekil 10. Atatürk Kültür Parkı'nda bulunan sosyal-kültürel birimler

\subsection{4. İ̧̧letme birimleri}

Parkın farklı bölgelerinde konumlanmış toplamda altı adet restoran $(1,2)$, çay bahçesi $(3)$ ve kafe $(4,5,6)$ bulunmaktadır. Bir adet de fidanlık ve sera bulunmaktadır. İşletme birimlerine ait görseller Şekil 11. ve 12.'de verilmiştir.
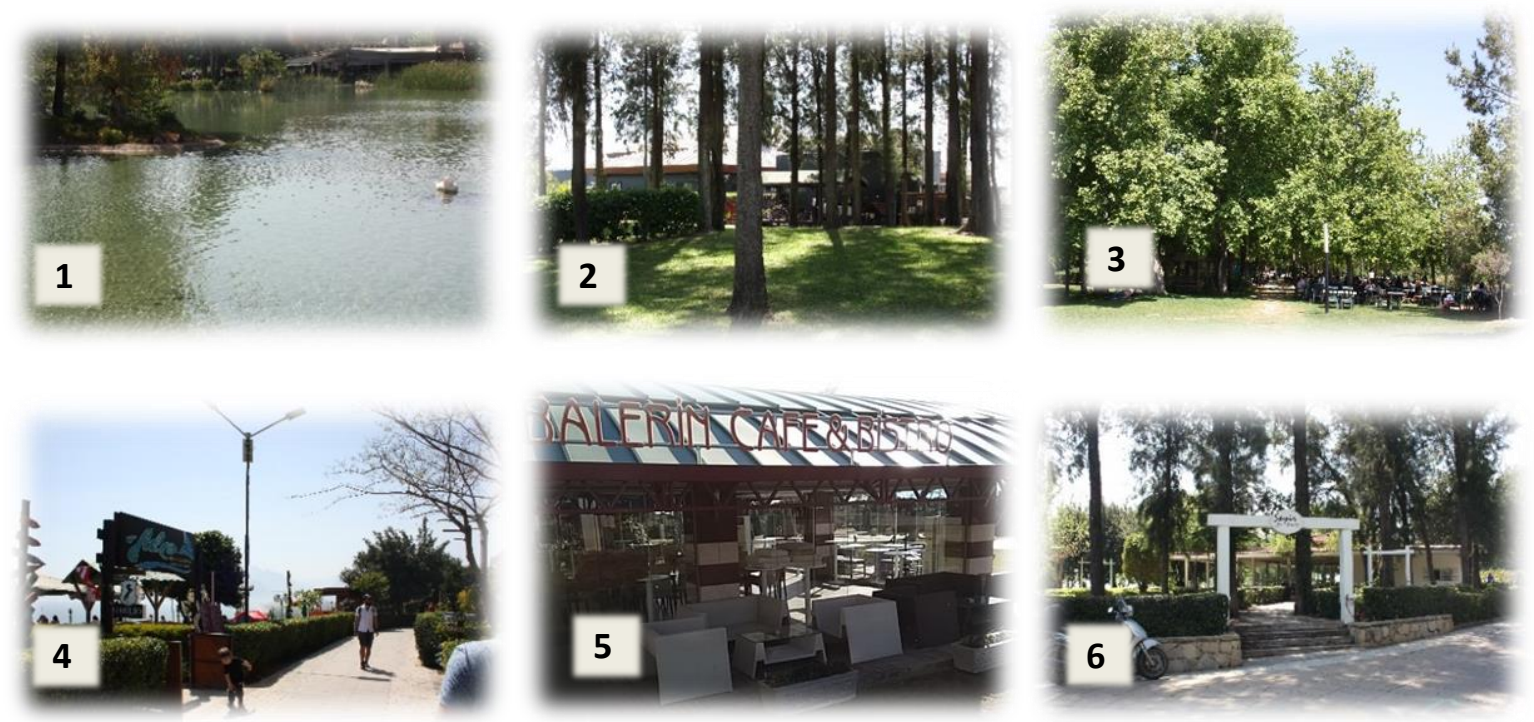

Şekil 11. Atatürk Kültür Parkı'nda bulunan işletme birimleri 


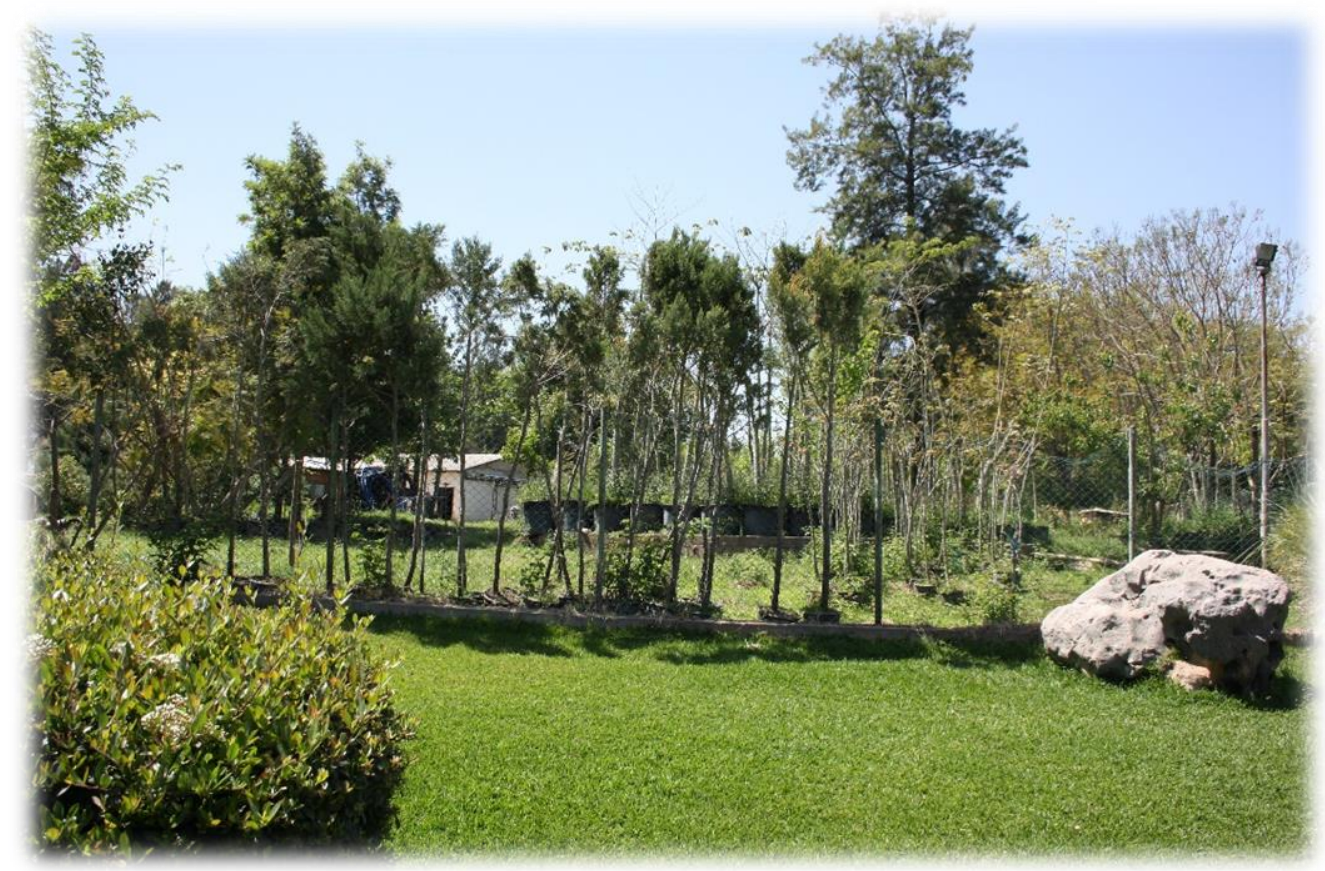

Şekil 12. Atatürk Kültür Parkı'nda bulunan fidanlık

\subsubsection{Hizmet birimleri}

Park bünyesinde; öngörülen hizmet birimlerinden, idari ünite olarak parkın güney-batı yönünde bir yönetim ofisi (1), ana girişin doğu (2) ve batı (3) yönünde olmak üzere iki farklı yerde otopark bulunmaktadır. Tuvaletler ise diğer kullanım birimlerinin içerisinde bulunmaktadır (Kafe ve restoranlar gibi). Hizmet birimlerine ait görsel Şekil 13'te verilmiştir.
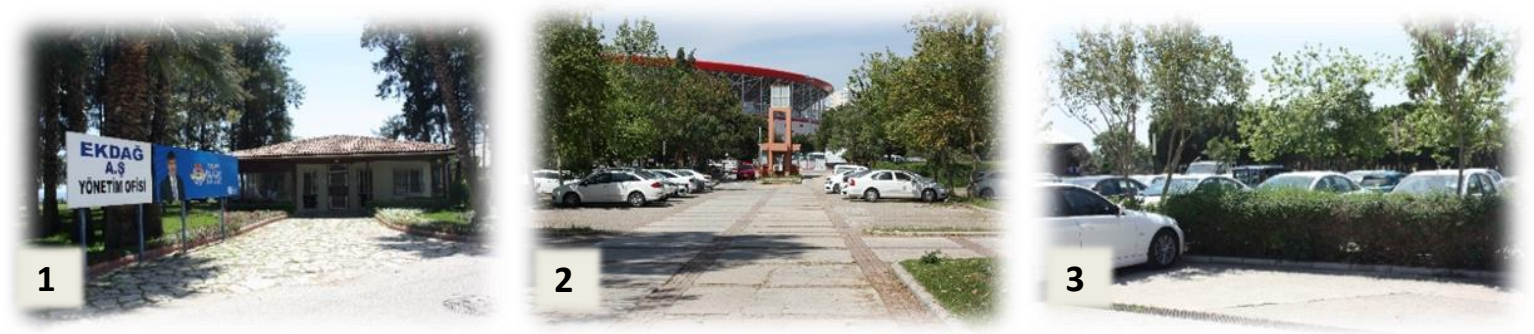

Şekil 13. Atatürk Kültür Parkı'nda bulunan hizmet birimleri

\subsection{Anket sonuçları}

\subsubsection{Kullanıcıların sosyo-demografik durumlarının ve park kullanımına yönelik dağılımları}

Çalışmaya katılan kullanııların demografik özellikleri incelendiğinde; kullanıcıların cinsiyet dağııııında $\% 52,3^{\prime}$ ü kadın, \%47,7'si erkektir. Kullanıcıların \%23,8'i 18-25, \%30,8'i 26-35, \%17,3'ü 36-45, \%14,0'ü $46-55$ ve $\% 6,00$ 'sı 56-65 yaş aralığında ve\%8,2'si 65 yaş üstündedir. Kullanıcıların \%63,0'ü evli, \%37,0'si bekârdır ve \%56,0'sı çocuk sahibi iken \%44,0'ü değildir. Kullanıcıların \%10,0'u ilkokul, \%8,3'ü ortaokul, $\% 34,2^{\prime}$ si lise, \%43,0'ü lisans ve \%4,5'i lisansüstü mezunu düzeyinde kullanıcılardır. Kullanııların; $\% 15,0$ 'i kamu sektörü, \%43,0'ü özel sektör çalışanıdır. \%16,0'sı öğrenci, $\% 8,0$ 'i ev hanımı, $\% 12,5^{\prime}$ i emekli grubunda ve $\% 5,5^{\prime} i$ diğer meslek gruplarında yer aldığı görülmüştür. Gelir durumlarının dağılımlarında kullanıcıların; \%24,5'i 2000 TL ve altı, \%39,7'sinin 2000-3000 TL, \%29,3'ü 3000-5000 TL ve $\% 6,5^{\prime}$ i 5000 TL ve üstü gelire sahip olduğu belirlenmiştir.

Kullanıcıların Atatürk Kültür Parkı'nı tercih etme sebepleri incelendiğinde; \%18,3 oranla görsel çekicilik ve estetiğin ön planda olduğu saptanmıştır. Kullanıcıların en çok kullandıkları alanlar; $\% 17,6$ oranla yaya gezinti alanları ve $\% 17,5$ oranla çay bahçeleri, kafe ve restoranlar olduğu saptanmıştır. Kullanıcıların parkı; \%25,5 oranla en fazla temiz hava almak ve stresten uzaklaşmak amacı ile kullandıkları belirlenmiştir (Çizelge 2). 
Çizelge 2. Atatürk Kültür Parkı kullanımına yönelik dağılımlar

Atatürk Kültür Parkı'nı Tercih Etme Sebebi

\begin{tabular}{|c|c|c|c|}
\hline & & n (kişi sayısı) & \% (yüzde) \\
\hline \multirow{9}{*}{$\begin{array}{l}\text { Atatürk Kültür Parkı'nı } \\
\text { Tercih Etme Sebebi }\end{array}$} & Park büyüklüg̈ü & 133 & 14,6 \\
\hline & Çevre düzenlemesi & 84 & 9,2 \\
\hline & Erişilebilirlik (kolay ulaşım) & 128 & 14,0 \\
\hline & Fiziksel durum & 75 & 8,2 \\
\hline & Kullanım birimleri ve yapılı çevre & 127 & 13,9 \\
\hline & Güvenlik & 37 & 4,0 \\
\hline & Görsel çekicilik ve estetik & 166 & 18,3 \\
\hline & Su öğeleri & 46 & 5,0 \\
\hline & Gölgeli ve güneşli alanlar & 117 & 12,8 \\
\hline \multirow{14}{*}{$\begin{array}{l}\text { Atatürk Kültür Parkı'nda En } \\
\text { Çok Kullanılan Alanlar }\end{array}$} & Yapay göller, büyük su alanları & 56 & 5,3 \\
\hline & Piknik alanları & 75 & 7,1 \\
\hline & Yaya gezinti alanları & 187 & 17,6 \\
\hline & Bisiklet yolları & 24 & 2,2 \\
\hline & Fidanlık ve seralar & 13 & 1,2 \\
\hline & Spor alanları & 44 & 4,1 \\
\hline & Çocuk oyun alanları & 51 & 4,8 \\
\hline & Oturma yerleri & 165 & 15,6 \\
\hline & Antalya Büyükşehir Belediyesi Anaokulu & 26 & 2,5 \\
\hline & Konser alanları & 65 & 6,1 \\
\hline & Tiyatro alanları & 50 & 4,7 \\
\hline & Fuar alanları & 72 & 6,8 \\
\hline & Açık hava sergileri & 48 & 4,5 \\
\hline & Çay bahçeleri, kafe, restoranlar & 186 & 17,5 \\
\hline \multirow{11}{*}{$\begin{array}{l}\text { Atatürk Kültür Parkı'nı } \\
\text { Kullanma Amacı }\end{array}$} & Spor alanları & 54 & 5,3 \\
\hline & Çocuk oyun alanları & 63 & 6,1 \\
\hline & Piknik yapmak & 68 & 6,6 \\
\hline & Aile veya yakınlar ile vakit geçirmek & 163 & 15,9 \\
\hline & Buluşma merkezi olarak & 95 & 9,2 \\
\hline & Etrafı ve manzarayı seyretmek & 169 & 16,5 \\
\hline & Kültürel aktiviteler (konser, tiyatro vb.) & 101 & 9,8 \\
\hline & Eğitim (anaokulu) & 25 & 2,4 \\
\hline & Bilimsel araştırma & 6 & 0,6 \\
\hline & Sanatsal aktiviteler (fotoğraf çekimi, resim çizme vb.) & 22 & 2,1 \\
\hline & Temiz hava almak, stresten uzaklaşmak & 262 & 25,5 \\
\hline
\end{tabular}

\subsubsection{Chi-square (Ki-kare) testi ile yapılan karşılaştırma sonuçları}

Kullanıcıların cinsiyete göre parkı tercih etme nedenleri incelendiğinde istatistiksel olarak erişilebilirlik nedeni ile anlamlı farklılık göstermektedir ( $x^{2}: 5,694 \mathrm{df:1}$ p:0,017). Kadınların \%15,7'si erişilebilirliğ tercih ederken erkeklerin \%12,0'si tercih etmektedir (Çizelge 3 ).

Kullanıcıların yaş gruplarına göre parkı tercih etme nedenleri incelendiğinde istatistiksel olarak görsel çekicilik kriteri ile anlamlı farklılık göstermektedir $\left(x^{2}: 13,868 \mathrm{df:5}\right.$ p:0,016). 46-55 yaş aralığındaki kullanıııların \%20,9'u görsel çekicilik nedeni ile parkı tercih ederken 65 yaş üstü kullanıcıların $\% 11,4^{\prime} u ̈$ tercih etmektedir (Çizelge 3).

Kullanıcıların çocuk sahibi olma durumlarına göre parkı tercih etme nedenleri incelendiğinde istatistiksel olarak kullanım birimleri ve yapılı çevre $\left(x^{2}: 5,790 \mathrm{df}: 1 \mathrm{p}: 0,016\right)$ ve görsel çekicilik $\left(x^{2}: 5,020\right.$ df:1 p:0,025) ile anlamlı farklılık göstermektedir. Çocuk sahibi olan kullanıııların \%12,0'si parktaki kullanım birimleri ve yapılı çevreyi tercih ederken, görsel çekicilik kriterini çocuk sahibi olmayan kullanıcıların \%20,3'ü tercih etmiştir (Çizelge 3).

Kullanıcıların eğitim durumlarına göre parkı tercih etme nedenleri incelendiğinde istatistiksel olarak çevre düzenlemesi $\left(x^{2}: 11,927 \mathrm{df}: 4 \mathrm{p}: 0,018\right)$, kullanım birimleri ve yapılı çevre $\left(x^{2}: 12,319 \mathrm{df}: 4 \mathrm{p}: 0,015\right)$ ile anlamlı farklılık göstermektedir. \%11,3 oranla lisans mezunu düzeyindeki kullanıcılar çevre düzenlemesini tercih ederken, $\% 25,0$ oranla lisansüstü mezunu düzeyindeki kullanıcıların kullanım birimleri ve yapılı çevreyi tercih etmektedir (Çizelge 3 ).

Kullanıcıların meslek gruplarına göre parkı tercih etme nedenleri incelendiğinde istatistiksel olarak erişilebilirlik ( $x^{2}: 13,554 \mathrm{df:5}$ p:0,019), görsel çekicilik ( $x^{2}: 26,974 \mathrm{df:5}$ p:0,000) kriterleri ile anlamlı 
farklılık göstermektedir. \%21,7 oranla emekli kullanıcılar erişilebilirliği tercih ederken, \%22,3 oranla özel sektör çalışanı kullanıcıların görsel çekiciliği tercih etmektedir (Çizelge 3).

Çizelge 3. Kullanıcıların Atatürk Kültür Parkı'nı tercih etme nedenleri

\begin{tabular}{|c|c|c|c|c|c|c|c|c|c|c|c|}
\hline \multicolumn{12}{|c|}{ Atatürk Kültür Parkı'nı Tercih Nedeni } \\
\hline & & & 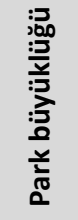 & Uू & 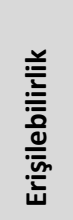 & $\begin{array}{l}\frac{E}{3} \\
\frac{2}{2} \\
\frac{0}{0} \\
\frac{y}{N} \\
\frac{\sqrt{2}}{4}\end{array}$ & 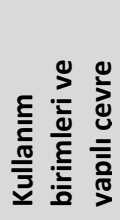 & 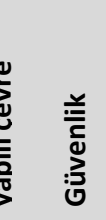 & 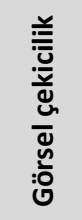 & 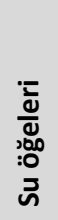 & $\frac{\frac{1}{\frac{\pi}{c}}}{\frac{\frac{1}{\pi}}{\pi}}$ \\
\hline \multirow{6}{*}{ 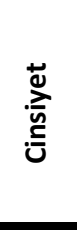 } & \multirow{2}{*}{ Kadın } & Sayı & 68 & 48 & 78 & 46 & 62 & 22 & 79 & 24 & 69 \\
\hline & & Yüzde & 13,7 & 9,7 & 15,7 & 9,3 & 12,5 & 4,4 & 15,9 & 4,8 & 13,9 \\
\hline & \multirow{2}{*}{ Erkek } & Sayı & 65 & 36 & 50 & 29 & 65 & 15 & 87 & 22 & 48 \\
\hline & & Yüzde & 15,6 & 8,6 & 12,0 & 6,9 & 15,6 & 3,6 & 20,9 & 5,3 & 11,5 \\
\hline & \multirow{2}{*}{ Toplam } & Sayı & 133 & 84 & 128 & 75 & 127 & 37 & 166 & 46 & 117 \\
\hline & & Yüzde & 14,6 & 9,2 & 14,0 & 8,2 & 13,9 & 4,1 & 18,2 & 5,0 & 12,8 \\
\hline \multirow{14}{*}{$\begin{array}{l}\frac{5}{\pi} \\
\frac{\pi}{2} \\
\frac{0}{0} \\
\text { in } \\
>\end{array}$} & \multirow[t]{2}{*}{$18-25$} & Sayı & 31 & 26 & 29 & 23 & 36 & 9 & 45 & 9 & 26 \\
\hline & & Yüzde & 13,2 & 11,1 & 12,4 & 9,8 & 15,4 & 3,9 & 19,2 & 3,9 & 11,1 \\
\hline & \multirow[t]{2}{*}{ 26-35 } & Sayı & 46 & 28 & 33 & 26 & 40 & 8 & 61 & 18 & 41 \\
\hline & & Yüzde & 15,3 & 9,3 & 11,0 & 8,6 & 13,3 & 2,6 & 20,3 & 6,0 & 13,6 \\
\hline & $36-45$ & Sayı & 24 & 10 & 27 & 11 & 25 & 3 & 20 & 5 & 17 \\
\hline & & Yüzde & 16,9 & 7,0 & 19,0 & 7,8 & 17,6 & 2,1 & 14,1 & 3,5 & 12,0 \\
\hline & $46-55$ & Sayı & 16 & 7 & 15 & 7 & 15 & 8 & 24 & 6 & 17 \\
\hline & & Yüzde & 13,9 & 6,1 & 13,0 & 6,1 & 13,0 & 7,0 & 20,9 & 5,2 & 14,8 \\
\hline & $56-65$ & Sayı & 9 & 4 & 8 & 4 & 6 & 5 & 8 & 3 & 4 \\
\hline & & Yüzde & 17,7 & 7,8 & 15,7 & 7,8 & 11,8 & 9,8 & 15,7 & 5,9 & 7,8 \\
\hline & $65<$ & Sayı & 7 & 9 & 16 & 4 & 5 & 4 & 8 & 5 & 12 \\
\hline & & Yüzde & 10,0 & 12,9 & 22,9 & 5,7 & 7,1 & 5,7 & 11,4 & 7,1 & 17,2 \\
\hline & Toplam & Sayı & 133 & 84 & 128 & 75 & 127 & 37 & 166 & 46 & 117 \\
\hline & & Yüzde & 14,6 & 9,2 & 14,0 & 8,2 & 13,9 & 4,1 & 18,2 & 5,0 & 12,8 \\
\hline \multirow{6}{*}{ 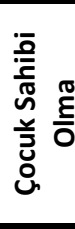 } & Var & Sayı & 73 & 43 & 79 & 43 & 60 & 25 & 82 & 29 & 65 \\
\hline & & Yüzde & 14,6 & 8,6 & 15,8 & 8,7 & 12,0 & 5,0 & 16,5 & 5,8 & 13,0 \\
\hline & Yok & Sayı & 60 & 41 & 49 & 32 & 67 & 12 & 84 & 17 & 52 \\
\hline & & Yüzde & 14,5 & 9,9 & 11,8 & 7,7 & 16,2 & 2,9 & 20,3 & 4,1 & 12,6 \\
\hline & Toplam & Sayı & 133 & 84 & 128 & 75 & 127 & 37 & 166 & 46 & 117 \\
\hline & & Yüzde & 14,6 & 9,2 & 14,0 & 8,2 & 13,9 & 4,1 & 18,2 & 5,0 & 12,8 \\
\hline \multirow{12}{*}{ 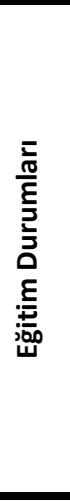 } & \multirow{2}{*}{ ilkokul } & Sayı & 14 & 6 & 17 & 3 & 4 & 2 & 14 & 7 & 9 \\
\hline & & Yüzde & 18,4 & 7,9 & 22,4 & 4,0 & 5,3 & 2,6 & 18,4 & 9,2 & 11,8 \\
\hline & \multirow[t]{2}{*}{ Ortaokul } & Sayı & 10 & 7 & 13 & 3 & 10 & 5 & 11 & 2 & 9 \\
\hline & & Yüzde & 14,3 & 10,0 & 18,6 & 4,3 & 14,3 & 7,1 & 15,7 & 2,8 & 12,9 \\
\hline & \multirow[t]{2}{*}{ Lise } & Sayı & 51 & 21 & 37 & 27 & 44 & 11 & 56 & 12 & 38 \\
\hline & & Yüzde & 17,2 & 7,1 & 12,4 & 9,1 & 14,8 & 3,7 & 18,9 & 4,0 & 12,8 \\
\hline & \multirow[t]{2}{*}{ Lisans } & Sayı & 54 & 49 & 56 & 36 & 60 & 18 & 79 & 22 & 60 \\
\hline & & Yüzde & 12,4 & 11,3 & 12,9 & 8,3 & 13,8 & 4,2 & 18,2 & 5,1 & 13,8 \\
\hline & \multirow[t]{2}{*}{$\begin{array}{c}\text { Lisans } \\
\text { üstü }\end{array}$} & Sayı & 4 & 1 & 5 & 6 & 9 & 1 & 6 & 3 & 1 \\
\hline & & Yüzde & 11,2 & 2,8 & 13,9 & 16,6 & 25,0 & 2,8 & 16,6 & 8,3 & 2,8 \\
\hline & \multirow[t]{2}{*}{ Toplam } & Sayı & 133 & 84 & 128 & 75 & 127 & 37 & 166 & 46 & 117 \\
\hline & & Yüzde & 14,6 & 9,2 & 14,0 & 8,2 & 13,9 & 4,1 & 18,2 & 5,0 & 12,8 \\
\hline & Kamu çalışanı & Sayı & 18 & 12 & 16 & 10 & 26 & 8 & 15 & 6 & 19 \\
\hline & & Yüzde & 13,9 & 9,2 & 12,3 & 7,7 & 20,0 & 6,2 & 11,5 & 4,6 & 14,6 \\
\hline & Özel sektör & Sayı & 57 & 36 & 42 & 27 & 55 & 13 & 88 & 24 & 53 \\
\hline & & Yüzde & 14,4 & 9,1 & 10,6 & 6,9 & 13,9 & 3,3 & 22,3 & 6,1 & 13,4 \\
\hline$\overline{\frac{5}{\pi}}$ & Öğrenci & Sayı & 22 & 17 & 24 & 16 & 22 & 5 & 32 & 5 & 15 \\
\hline$\frac{\pi}{2}$ & & Yüzde & 13,9 & 10,8 & 15,2 & 10,1 & 13,9 & 3,2 & 20,2 & 3,2 & 9,5 \\
\hline ㄴํㄴ & Ev hanımı & Sayı & 13 & 4 & 14 & 7 & 7 & 2 & 12 & 3 & 7 \\
\hline 弟 & & Yüzde & 18,8 & 5,8 & 20,3 & 10,2 & 10,2 & 2,9 & 17,3 & 4,3 & 10,2 \\
\hline$\overline{\underline{y}}$ & Emekli & Sayı & 14 & 11 & 23 & 11 & 11 & 8 & 9 & 4 & 15 \\
\hline & & Yüzde & 13,2 & 10,4 & 21,7 & 10,4 & 10,4 & 7,5 & 8,5 & 3,8 & 14,1 \\
\hline & Çalışmıyor & Sayı & 9 & 4 & 9 & 4 & 6 & 1 & 10 & 4 & 8 \\
\hline & & Yüzde & 16,4 & 7,3 & 16,4 & 7,3 & 10,9 & 1,8 & 18,1 & 7,3 & 14,5 \\
\hline & Toplam & Sayı & 133 & 84 & 128 & 75 & 127 & 37 & 166 & 46 & 117 \\
\hline & & Yüzde & 14,6 & 9,2 & 14,0 & 8,2 & 13,9 & 4,1 & 18,2 & 5,0 & 12,8 \\
\hline
\end{tabular}


Kullanıcıların cinsiyete göre parkta en çok kullandıkları alanlar incelendiğinde istatistiksel olarak bisiklet yolları ( $x^{2}: 6,481 \mathrm{df:1}$ p:0,006) ve çocuk oyun alanları ( $\left.\mathrm{x}^{2}: 5,554 \mathrm{df:1} \mathrm{p}: 0,018\right)$ ile anlamlı farklılık göstermektedir. Bisiklet yollarını; kadınların \%1,1'i kullanırken, erkeklerin \%3,6'sının kullandığı belirlenmiştir. Çocuk oyun alanlarını \%6,3 oranla en çok kadın kullanıcılar tarafından kullanıldığı tespit edilmiştir (Çizelge 4).

Kullanıcıların yaş gruplarına göre parkta en çok kullandıkları alanlar incelendiğinde istatistiksel olarak spor alanları ( $\left.x^{2}: 19,435 \mathrm{df}: 5 \mathrm{p}: 0,002\right)$, çocuk oyun alanları $\left(x^{2}: 24,904 \mathrm{df}: 5 \mathrm{p}: 0,000\right)$, anaokulu $\left(x^{2}: 18,914\right.$ df:5 p:0,002) ile anlamlı farklılık göstermektedir. Yine konser alanları $\left(x^{2}: 17,923 \mathrm{df:5}\right.$ p:0,003), tiyatro alanları ( $\left.x^{2}: 14,620 \mathrm{df:5} p: 0,012\right)$, açık hava sergi alanları ( $\left.x^{2}: 13,391 \mathrm{df:5} \mathrm{p}: 0,020\right)$, çay bahçeleri, kafe ve restoran ( $x^{2}: 11,421 \mathrm{df}: 5$ p:0,044) alanları ile anlamlı farklılık göstermektedir. Spor alanlarını \%6,5 oranla, konser alanlarını \%8,7 oranla ve tiyatro alanlarını \%6,1 oranla en çok 18-25 yaş aralığındaki kullanıcıların kullandığı belirlenmiştir. \%6,5 oranla açık hava sergi alanlarını en çok kullanan kullanııılar 26-35 yaş aralığında olduğu görülmüştür. \%10,2 oranla çocuk oyun alanlarını en çok 36-45, anaokulu ise $\% 9,9$ oranla 65 yaş üstü kullanıcılar kullanmaktadır. $\% 25,0$ oranla çay bahçeleri, kafe ve restoranları 56-65 yaş aralığındaki kullanıcıların daha fazla kullandığı görülmektedir (Çizelge 4).

Kullanıcıların çocuk sahibi olma durumlarına göre parkta en çok kullandıkları alanlar incelendiğinde istatistiksel olarak piknik alanları ( $\left.x^{2}: 8,059 \mathrm{df}: 1 \mathrm{p}: 0,005\right)$, bisiklet yolları $\left(\mathrm{x}^{2}: 4,390 \mathrm{df}: 1 \mathrm{p}: 0,036\right)$, spor alanları ( $\left.x^{2}: 5,283 \mathrm{df}: 1 \mathrm{p}: 0,022\right)$, çocuk oyun alanları $\left(x^{2}: 43,903 \mathrm{df:1} \mathrm{p}: 0,000\right)$ ile anlamlı farklılık göstermektedir. Yine konser alanları ( $\left.x^{2}: 25,240 \mathrm{df}: 1 \mathrm{p}: 0,000\right)$, tiyatro alanları $\left(x^{2}: 12,268 \mathrm{df}: 1 \mathrm{p}: 0,000\right)$, fuar alanları ( $\left.x^{2}: 14,096 \mathrm{df:1} p: 0,000\right)$ ve açık hava sergi alanları $\left(x^{2}: 17,201 \mathrm{df:1} p: 0,000\right)$ ve anaokulu ( $\left.\mathrm{x}^{2}: 16,495 \mathrm{df}: 1 \mathrm{p}: 0,000\right)$ alanları ile anlamlı farklılık göstermektedir. Çocuk sahibi olmayan kullanıcıların \%3,2'si bisiklet yollarını, \%5,4'ü spor alanlarını en çok kullandıkları alan olarak belirtmiştir. Yine çocuk sahibi olmayan kullanıııların en çok kullandıkları alanlar; \%9,4 oranla konser alanları, \%6,8 oranla tiyatro alanları, \%9,2 oranla fuar alanları, \%7,0 oranla açık hava sergi alanlar olarak saptanmıştır. Çocuk sahibi olan kullanıcıların en çok kullandıkları alanlar ise $\% 9,4$ ile piknik alanları ve $\% 4,4$ ile anaokuludur. Çocuk oyun alanlarını ise çocuk sahibi kullanıcıların \%9,1'i kullanırken çocuk sahibi olmayan kullanııılar kullanmamaktadır (Çizelge 4).

Kullanıcıların eğitim durumlarına göre parkta en çok kullandıkları alanlar incelendiğinde istatistiksel olarak piknik alanları ( $\left.x^{2}: 11,587 \mathrm{df}: 4 \mathrm{p}: 0,021\right)$ ile anlamlı farklılık göstermektedir. Yine konser alanları $\left(x^{2}: 24,959 \mathrm{df}: 4 \mathrm{p}: 0,000\right)$, tiyatro alanları $\left(x^{2}: 21,146 \mathrm{df}: 4 \mathrm{p}: 0,000\right)$, fuar alanları $\left(x^{2}: 17,862 \mathrm{df}: 4 \mathrm{p}: 0,001\right)$ ve açık hava sergi alanları $\left(x^{2}: 38,464\right.$ df:4 p:0,000) anlamlı farklılık göstermektedir. Piknik alanları; $\% 14,1$ oranla en çok ortaokul mezunu düzeyindeki kullanıcılar tarafından kullanılmaktadır. Konser alanlarını $\% 10,0$, tiyatro ve fuar alanlarını $\% 11,7, \% 13,3$ oranla açık hava sergi alanlarını en çok kullanan kullanıcıların lisansüstü mezunu düzeyindeki kullanıcılar olduğu görülmüştür (Çizelge 4).

Kullanıcıların meslek gruplarına göre parkta en çok kullandıkları alanlar incelendiğinde istatistiksel olarak piknik alanları ( $x^{2}: 21,985 \mathrm{df}: 5$ p:0,001), bisiklet yolları ( $\left.x^{2}: 11,590 \mathrm{df}: 5 \mathrm{p}: 0,041\right)$, çocuk oyun alanları $\left(x^{2}: 34,968\right.$ df:5 p:0,000) ve anaokulu $\left(x^{2}: 15,870\right.$ df:5 p:0,007) ile anlamlı farklılık göstermektedir. Yine konser alanları ( $x^{2}: 21,280 \mathrm{df:5}$ p:0,001), tiyatro alanları ( $\left.x^{2}: 13,146 \mathrm{df}: 5 \mathrm{p}: 0,022\right)$, fuar alanları ( $\left.x^{2}: 19,067 \mathrm{df}: 5 \mathrm{p}: 0,002\right)$ ve çay bahçeleri, kafe ve restaurantlar $\left(x^{2}: 16,498 \mathrm{df}: 5 \mathrm{p}: 0,006\right)$ ile anlamlı farklılık göstermektedir. Piknik alanları; \%20,6 oranla en çok ev hanımı kullanıcılar, bisiklet yollarını ise $\% 4,8$ oranla öğrenciler tarafından kullanılmaktadır. Çocuk oyun alanlarını ise $\% 16,4$ ile ev hanımları kullanmakta öğrenciler ise kullanmamaktadır. Anaokulunu \%7,6 oranla en çok emekli grubu kullanmaktadır. Öğrencilerin $\% 10,8^{\prime} i$ konser alanlarını, $\% 8,1^{\prime} i$ tiyatro ve $\% 11,8^{\prime} i$ fuar alanlarını en çok kullandıkları alanlar olduğu görülmüştür. \%21,0 oranla ise çay bahçeleri, kafe ve restaurantları en çok kullanan kullanıcılar emekli grubu olduğu tespit edilmiştir (Çizelge 4). 
Çizelge 4. Kullanıcıların Atatürk Kültür Parkı'nda en çok kullanılan alanlar

\begin{tabular}{|c|c|c|c|c|c|c|c|c|c|c|c|c|c|c|c|c|}
\hline \multicolumn{17}{|c|}{ Atatürk Kültür Parkı'nda En Çok Kullanılan Alanlar } \\
\hline & & & 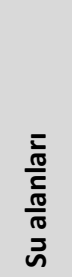 & 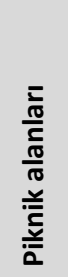 & 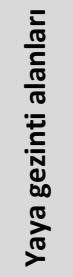 & 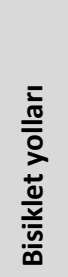 & 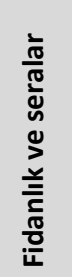 & 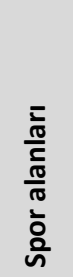 & $\begin{array}{l}\frac{1}{\pi} \\
\frac{\pi}{2} \\
\frac{\pi}{\pi} \\
\frac{5}{3} \\
0 \\
0 \\
\frac{y}{3} \\
0 \\
ن\end{array}$ & 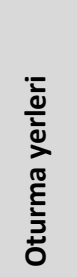 & $\begin{array}{l}\frac{3}{3} \\
\frac{1}{0} \\
\frac{0}{0} \\
\frac{c}{4}\end{array}$ & 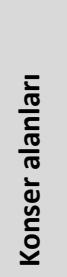 & 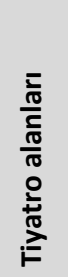 & $\begin{array}{l}\frac{5}{\frac{1}{0}} \\
\frac{5}{\pi} \\
\frac{10}{\pi} \\
\frac{\pi}{3} \\
\frac{1}{4}\end{array}$ & 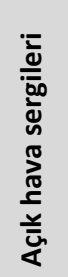 & 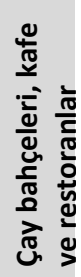 \\
\hline \multirow{6}{*}{ 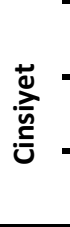 } & \multirow{2}{*}{ Kadın } & Sayı & 25 & 45 & 92 & 6 & 5 & 21 & 35 & 88 & 16 & 36 & 27 & 38 & 27 & 92 \\
\hline & & Yüzde & 4,5 & 8,2 & 16,6 & 1,1 & 0,9 & 3,8 & 6,3 & 15,9 & 2,9 & 6,5 & 4,9 & 6,9 & 4,9 & 16,6 \\
\hline & \multirow{2}{*}{ Erkek } & Sayı & 31 & 30 & 95 & 18 & 8 & 23 & 16 & 77 & 10 & 29 & 23 & 34 & 21 & 94 \\
\hline & & Yüzde & 6,1 & 5,9 & 18,7 & 3,6 & 1,6 & 4,5 & 3,1 & 15,1 & 1,9 & 5,7 & 4,5 & 6,7 & 4,1 & 18,5 \\
\hline & \multirow{2}{*}{ Toplam } & Sayı & 56 & 75 & 187 & 24 & 13 & 44 & 51 & 165 & 26 & 65 & 50 & 72 & 48 & 186 \\
\hline & & Yüzde & 5,3 & 7,1 & 17,6 & 2,3 & 1,2 & 4,1 & 4,8 & 15,5 & 2,5 & 6,1 & 4,7 & 6,8 & 4,5 & 17,5 \\
\hline \multirow{14}{*}{$\begin{array}{l}\frac{5}{\pi} \\
\frac{10}{0} \\
\frac{2}{2} \\
\frac{1}{0} \\
\text { m }\end{array}$} & \multirow{2}{*}{$18-25$} & Sayı & 16 & 17 & 45 & 10 & 2 & 17 & 1 & 46 & 2 & 23 & 16 & 21 & 10 & 37 \\
\hline & & Yüzde & 6,1 & 6,5 & 17,1 & 3,8 & 0,70 & 6,5 & 0,40 & 17,5 & 0,80 & 8,7 & 6,1 & 8,0 & 3,8 & 14,1 \\
\hline & \multirow{2}{*}{$26-35$} & Sayı & 16 & 22 & 60 & 9 & 3 & 20 & 22 & 56 & 4 & 26 & 23 & 29 & 25 & 69 \\
\hline & & Yüzde & 4,2 & 5,7 & 15,6 & 2,3 & 0,80 & 5,2 & 5,7 & 14,6 & 1,0 & 6,8 & 6,0 & 7,6 & 6,5 & 18,0 \\
\hline & \multirow{2}{*}{$36-45$} & Sayı & 6 & 14 & 32 & 2 & 1 & - & 17 & 21 & 6 & 10 & 7 & 12 & 6 & 33 \\
\hline & & Yüzde & 3,6 & 8,4 & 19,1 & 1,2 & 0,60 & 0,00 & 10,2 & 12,6 & 3,6 & 6,0 & 4,2 & 7,2 & 3,6 & 19,7 \\
\hline & \multirow{2}{*}{$46-55$} & Sayı & 10 & 14 & 21 & 2 & 5 & 3 & 6 & 19 & 4 & 5 & 2 & 5 & 5 & 20 \\
\hline & & Yüzde & 8,2 & 11,6 & 17,4 & 1,7 & 4,1 & 2,5 & 4,9 & 15,7 & 3,3 & 4,1 & 1,7 & 4,1 & 4,1 & 16,6 \\
\hline & \multirow{2}{*}{$56-65$} & Sayı & 4 & 4 & 10 & 1 & 1 & 2 & 3 & 9 & 3 & 1 & 1 & 2 & 1 & 14 \\
\hline & & Yüzde & 7,1 & 7,1 & 17,9 & 1,8 & 1,8 & 3,6 & 5,3 & 16,1 & 5,3 & 1,8 & 1,8 & 3,6 & 1,8 & 25,0 \\
\hline & \multirow{2}{*}{65 üstü } & Sayı & 4 & 4 & 19 & - & 1 & 2 & 2 & 14 & 7 & - & 1 & 3 & 1 & 13 \\
\hline & & Yüzde & 5,6 & 5,6 & 26,8 & 0,00 & 1,4 & 2,8 & 2,8 & 19,7 & 9,9 & 0,00 & 1,4 & 4,2 & 1,4 & 18,3 \\
\hline & \multirow{2}{*}{ Toplam } & Sayı & 56 & 75 & 187 & 24 & 13 & 44 & 51 & 165 & 26 & 65 & 50 & 72 & 48 & 186 \\
\hline & & Yüzde & 5,3 & 7,1 & 17,6 & 2,3 & 1,2 & 4,1 & 4,8 & 15,5 & 2,5 & 6,1 & 4,7 & 6,8 & 4,5 & 17,5 \\
\hline \multirow{6}{*}{ 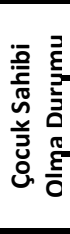 } & Var & Sayı & 32 & 53 & 107 & 8 & 8 & 17 & 51 & 90 & 25 & 18 & 16 & 26 & 13 & 99 \\
\hline & var & Yüzde & 5,7 & 9,4 & 19,0 & 1,4 & 1,4 & 3,0 & 9,1 & 16,0 & 4,4 & 3,2 & 2,8 & 4,6 & 2,3 & 17,6 \\
\hline & Yol & Sayı & 24 & 22 & 80 & 16 & 5 & 27 & - & 75 & 1 & 47 & 34 & 46 & 35 & 87 \\
\hline & rok & Yüzde & 4,8 & 4,4 & 16,0 & 3,2 & 1,0 & 5,4 & 0,00 & 15,0 & 0,20 & 9,4 & 6,8 & 9,2 & 7,0 & 17,5 \\
\hline & Tonlam & Sayı & 56 & 75 & 187 & 24 & 13 & 44 & 51 & 165 & 26 & 65 & 50 & 72 & 48 & 186 \\
\hline & Topram & Yüzde & 5,3 & 7,1 & 17,6 & 2,3 & 1,2 & 4,1 & 4,8 & 15,5 & 2,5 & 6,1 & 4,7 & 6,8 & 4,5 & 17,5 \\
\hline & iUlroln & Sayı & 8 & 11 & 17 & - & 1 & 1 & 7 & 18 & 3 & - & 2 & 6 & 2 & 17 \\
\hline & ПККОКИІ & Yüzde & 8,6 & 11,8 & 18,3 & 0,00 & 1,1 & 1,1 & 7,5 & 19,3 & 3,2 & 0,00 & 2,2 & 6,5 & 2,2 & 18,3 \\
\hline & Ortaokul & Sayı & 3 & 10 & 14 & - & 2 & 1 & 7 & 9 & 5 & 3 & 2 & 4 & 1 & 10 \\
\hline & Urtaokul & Yüzde & 4,2 & 14,1 & 19,7 & 0,00 & 2,8 & 1,4 & 9,9 & 12,7 & 7,0 & 4,2 & 2,8 & 5,6 & 1,4 & 14,1 \\
\hline ह & lice & Sayı & 19 & 29 & 60 & 8 & 4 & 14 & 19 & 55 & 9 & 14 & 10 & 13 & 5 & 71 \\
\hline ডั้ & Lise & Yüzde & 5,8 & 8,8 & 18,2 & 2,4 & 1,2 & 4,2 & 5,8 & 16,7 & 2,7 & 4,2 & 3,0 & 4,0 & 1,5 & 21,5 \\
\hline$\varepsilon$ & licanc & Sayı & 23 & 25 & 88 & 14 & 5 & 24 & 17 & 78 & 9 & 42 & 29 & 42 & 32 & 80 \\
\hline 湍要 & Lisans & Yüzde & 4,5 & 4,9 & 17,3 & 2,8 & 1,0 & 4,7 & 3,3 & 15,4 & 1,8 & 8,3 & 5,7 & 8,3 & 6,3 & 15,7 \\
\hline & Lisans & Sayı & 3 & - & 8 & 2 & 1 & 4 & 1 & 5 & - & 6 & 7 & 7 & 8 & 8 \\
\hline & üstü & Yüzde & 5,0 & 0,00 & 13,3 & 3,3 & 1,7 & 6,7 & 1,7 & 8,3 & 0,00 & 10,0 & 11,7 & 11,7 & 13,3 & 13,3 \\
\hline & & Sayı & 56 & 75 & 187 & 24 & 13 & 44 & 51 & 165 & 26 & 65 & 50 & 72 & 48 & 186 \\
\hline & Ioplam & Yüzde & 5,3 & 7,1 & 17,6 & 2,3 & 1,2 & 4,1 & 4,8 & 15,5 & 2,5 & 6,1 & 4,7 & 6,8 & 4,5 & 17,5 \\
\hline & Kamu & Sayı & 8 & 10 & 25 & 2 & - & 6 & 13 & 21 & 4 & 12 & 10 & 13 & 12 & 35 \\
\hline & çalışanı & Yüzde & 4,7 & 5,8 & 14,6 & 1,2 & 0,00 & 3,5 & 7,6 & 12,3 & 2,3 & 7,0 & 5,8 & 7,6 & 7,0 & 20,5 \\
\hline & Özel & Sayı & 31 & 34 & 80 & 10 & 8 & 15 & 22 & 69 & 9 & 28 & 19 & 25 & 20 & 87 \\
\hline & sektör & Yüzde & 6,8 & 7,4 & 17,5 & 2,2 & 1,8 & 3,3 & 4,8 & 15,1 & 2,0 & 6,1 & 4,2 & 5,5 & 4,4 & 19,0 \\
\hline & Ö̆̆renci & Sayı & 5 & 7 & 36 & 9 & 2 & 12 & - & 27 & 1 & 20 & 15 & 22 & 11 & 19 \\
\hline$\frac{10}{2}$ & Ugrencl & Yüzde & 2,7 & 3,8 & 19,3 & 4,8 & 1,1 & 6,4 & 0,00 & 14,5 & 0,5 & 10,8 & 8,1 & 11,8 & 5,9 & 10,2 \\
\hline 는 & Fuhanum & Sayı & 3 & 15 & 9 & - & 2 & 1 & 12 & 11 & 3 & 2 & 3 & 2 & 1 & 9 \\
\hline 首 & EV nanimı & Yüzde & 4,1 & 20,6 & 12,3 & 0,00 & 2,7 & 1,4 & 16,4 & 15,1 & 4,1 & 2,7 & 4,1 & 2,7 & 1,4 & 12,3 \\
\hline$\overline{\underline{g}}$ & Fmekli & Sayı & 3 & 5 & 29 & 3 & - & 6 & 2 & 25 & 9 & 2 & 2 & 5 & 3 & 25 \\
\hline 5 & EmekII & Yüzde & 2,5 & 4,2 & 24,4 & 2,5 & 0,00 & 5,0 & 1,7 & 21,0 & 7,6 & 1,7 & 1,7 & 4,2 & 2,5 & 21,0 \\
\hline & Calise & Sayı & 6 & 4 & 8 & - & 1 & 4 & 2 & 12 & - & 1 & 1 & 5 & 1 & 11 \\
\hline & Çallşmıyor & Yüzde & 10,7 & 7,1 & 14,3 & 0,00 & 1,8 & 7,1 & 3,6 & 21,4 & 0,00 & 1,8 & 1,8 & 8,9 & 1,8 & 19,6 \\
\hline & & Sayı & 56 & 75 & 187 & 24 & 13 & 44 & 51 & 165 & 26 & 65 & 50 & 72 & 48 & 186 \\
\hline & Iopla & Yüzde & 5,3 & 7,1 & 17,6 & 2,3 & 1,2 & 4,1 & 4,8 & 15,5 & 2,5 & 6,1 & 4,7 & 6,8 & 4,5 & 17,5 \\
\hline
\end{tabular}


Kullanıcıların cinsiyete göre parkı kullanma amaçları incelendiğinde istatistiksel olarak çocuk oyun alanları ( $x^{2}: 7,677$ df:1 p:0,006) ile anlamlı farklılık göstermektedir. Çocuk oyun alanlarını \%7,7 oranla en çok kadın, \%4,3 oranla erkek kullanııılar tarafından kullanıldığı tespit edilmiştir (Çizelge 5).

Kullanıcıların yaş gruplarına göre parkı kullanma amaçları incelendiğinde istatistiksel olarak spor alanları ( $\left.x^{2}: 15,506 \mathrm{df}: 5 \mathrm{p}: 0,008\right)$, çocuk oyun alanları $\left(\mathrm{x}^{2}: 24,699 \mathrm{df}: 5 \mathrm{p}: 0,000\right)$, buluşma merkezi amacı $\left(x^{2}: 38,794 \mathrm{df}: 5 \mathrm{p}: 0,000\right)$ ile anlamlı farklılık göstermektedir. Yine kültürel aktive amacı $\left(x^{2}: 23,967 \mathrm{df:5}\right.$ p:0,000), eğitim amacı ( $x^{2}: 22,337 \mathrm{df}: 5$ p:0,000) ile anlamlı farklılık göstermektedir. Spor alanları \%7,3 oranla 26-35 yaş aralığındaki kullanıcılar, çocuk oyun alanları \%11,4 oranla 36-45 yaş aralığındaki kullanıcılar ve buluşma merkezi amacı ile \%16,0 oranla 18-25 yaş aralığında kullanıcılar tarafından kullanılmaktadır. \%9,7 oranla 65 yaş üstü kullanıcıların anaokulu ve \%13,7 oranla 18-25 yaş aralığındaki kullanıcıların parkı kültürel aktivite amacı ile kullandıkları görülmektedir (Çizelge 5).

Kullanıcıların çocuk sahibi olma durumuna göre parkı kullanma amaçları incelendiğinde istatistiksel olarak çocuk oyun alanları ( $\left.x^{2}: 50,581 \mathrm{df}: 1 \mathrm{p}: 0,000\right)$, aile ve yakınlar ile vakit geçirmek $\left(x^{2}: 18,041 \mathrm{df}: 1\right.$ p:0,000) amacı ile anlamlı farklılık göstermektedir. Buluşma merkezi olarak ( $\left.x^{2}: 22,861 \mathrm{df}: 1 \mathrm{p}: 0,000\right)$, etrafı ve manzarayı seyretmek ( $\left.x^{2}: 11,514 \mathrm{df}: 1 \mathrm{p}: 0,001\right)$ amacı ile anlamlı farklılık göstermektedir. Yine kültürel aktivite amacı $\left(x^{2}: 35,120 \mathrm{df}: 1 \mathrm{p}: 0,000\right)$ ve eğitim $\left(x^{2}: 15,628 \mathrm{df}: 1\right.$ p:0,000) amacı ile anlamlı farklılık göstermektedir. Çocuk sahibi olan kullanıııların $\% 10,7$ oranla çocuk oyun alanlarını, $\% 4,2$ oranla eğitim amacı ve \%19,7 oranla aile ve yakınlar ile vakit geçirmek amacı ile kullanmaktadır. Çocuk sahibi olmayan kullanıcıların \%13,5 oranla buluşma merkezi olarak, $\% 19,8$ oranla etrafı ve manzarayı seyretmek ve \%15,2 oranla kültürel aktivite amacı ile kullanmaktadır (Çizelge 5).

Kullanıcıların eğitim durumlarına göre parkı kullanma amaçları incelendiğinde istatistiksel olarak spor alanları ( $\left.x^{2}: 12,628 \mathrm{df}: 4 \mathrm{p}: 0,013\right)$, piknik yapmak $\left(x^{2}: 13,174 \mathrm{df}: 4 \mathrm{p}: 0,010\right)$, buluşma merkezi $\left(x^{2}: 20,373\right.$ df:4 p:0,000) ve kültürel aktivite $\left(x^{2}: 27,228 \mathrm{df:4} p: 0,000\right)$ amacı ile anlamlı farklılık göstermektedir. Park; \%11,6 oranla spor amacı ve \%16,3 oranla kültürel aktivite amacı ile lisansüstü mezunu düzeyindeki kullanıcılar tarafından kullanılmaktadır. Park; lisans mezunu düzeyindeki kullanıcılar tarafından \%11,3 oranla buluşma merkezi amacı ile ve \%15,3 oranla ilkokul mezunu düzeyindeki kullanıcılar tarafından piknik yapma amacı ile kullanılmaktadır (Çizelge 5).

Kullanıcıların meslek gruplarına göre parkı kullanma amaçları incelendiğinde istatistiksel olarak çocuk oyun alanları ( $x^{2}: 32,415 \mathrm{df:5}$ p:0,000), piknik yapmak ( $x^{2}: 16,755 \mathrm{df:5}$ p:0,005) amacı ile anlamlı farklılık göstermektedir. Bununla birlikte aile ve yakınlar ile vakit geçirmek $\left(x^{2}: 12,118 \mathrm{df}: 5 \mathrm{p}: 0,033\right)$, buluşma merkezi $\left(x^{2}: 18,342\right.$ df:5 p:0,003) amacı ile anlamlı farklılık göstermektedir. Yine kültürel aktivite $\left(x^{2}: 32,276\right.$ df:5 p:0,000), eğitim ( $x^{2}: 19,243 \mathrm{df}: 5$ p:0,002), sanatsal aktivite $\left(x^{2}: 13,737 \mathrm{df:5}\right.$ p:0,017) amaçları ile anlamlı farklıık göstermektedir. Ev hanımı kullanıcılar parkı; \%16,2 oranla çocuk oyun alanları ve piknik yapmak, $\% 20,0$ oranla aile ve yakınlar ile vakit geçirmek amacıyla kullanmaktadır. Anaokulunu \%7,8 oranla eğitim amacı ile emekli grubu kullanmaktadır. Öğrencilerin \%14,0'ü buluşma merkezi olarak, $\% 16,8^{\prime} i$ kültürel aktivite ve $\% 5,1^{\prime} i$ sanatsal aktiviteler için parkı kullandıkları görülmüştür (Çizelge 5). 
Çizelge 5. Kullanıcıların Atatürk Kültür Parkı'nı kullanma amaçları

\begin{tabular}{|c|c|c|c|c|c|c|c|c|c|c|c|c|c|}
\hline \multicolumn{14}{|c|}{ Atatürk Kültür Parkı’nı Kullanma Amacı } \\
\hline & & & $\begin{array}{l}\frac{2}{\frac{1}{0}} \\
\frac{c}{\pi} \\
\frac{\pi}{\pi} \\
\frac{1}{0} \\
\frac{0}{n}\end{array}$ & 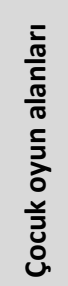 & 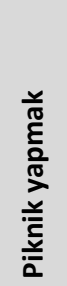 & 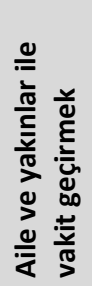 & 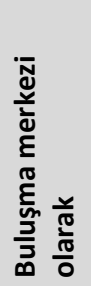 & 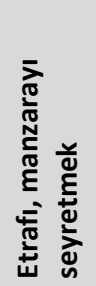 & 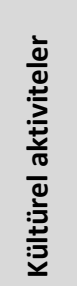 & 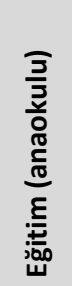 & 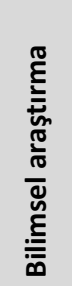 & 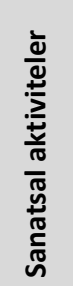 & 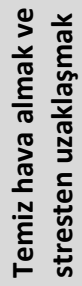 \\
\hline \multirow{6}{*}{ 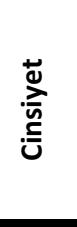 } & \multirow{2}{*}{ Kadın } & Sayı & 27 & 43 & 42 & 88 & 52 & 89 & 57 & 16 & 2 & 13 & 130 \\
\hline & & Yüzde & 4,8 & 7,7 & 7,5 & 15,7 & 9,3 & 15,9 & 10,2 & 2,9 & 0,4 & 2,3 & 23,3 \\
\hline & \multirow{2}{*}{ Erkek } & Sayı & 27 & 20 & 26 & 75 & 43 & 80 & 44 & 9 & 4 & 9 & 132 \\
\hline & & Yüzde & 5,8 & 4,3 & 5,5 & 16,0 & 9,2 & 17,1 & 9,4 & 1,9 & 0,9 & 1,9 & 28,1 \\
\hline & \multirow{2}{*}{ Toplam } & Sayı & 54 & 63 & 68 & 163 & 95 & 169 & 101 & 25 & 6 & 22 & 262 \\
\hline & & Yüzde & 5,3 & 6,1 & 6,6 & 15,9 & 9,2 & 16,4 & 9,8 & 2,4 & 0,6 & 2,2 & 25,5 \\
\hline \multirow{14}{*}{ 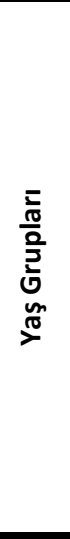 } & \multirow{2}{*}{$18-25$} & Sayı & 15 & 3 & 13 & 29 & 41 & 46 & 35 & 1 & 1 & 9 & 63 \\
\hline & & Yüzde & 5,8 & 1,2 & 5,1 & 11,3 & 16,0 & 18,0 & 13,7 & 0,4 & 0,4 & 3,5 & 24,6 \\
\hline & \multirow{2}{*}{$26-35$} & Sayı & 27 & 27 & 23 & 58 & 34 & 58 & 37 & 4 & 4 & 10 & 87 \\
\hline & & Yüzde & 7,3 & 7,3 & 6,2 & 15,7 & 9,2 & 15,7 & 10,0 & 1,1 & 1,1 & 2,7 & 23,6 \\
\hline & \multirow{2}{*}{$36-45$} & Sayı & 4 & 18 & 11 & 28 & 6 & 24 & 18 & 7 & 1 & 2 & 39 \\
\hline & & Yüzde & 2,5 & 11,4 & 7,0 & 17,7 & 3,8 & 15,2 & 11,4 & 4,4 & 0,6 & 1,3 & 24,7 \\
\hline & \multirow{2}{*}{$46-55$} & Sayı & 4 & 10 & 13 & 26 & 5 & 17 & 8 & 3 & - & 1 & 33 \\
\hline & & Yüzde & 3,3 & 8,3 & 10,8 & 21,7 & 4,2 & 14,2 & 6,7 & 2,5 & 0,00 & 0,80 & 27,5 \\
\hline & \multirow{2}{*}{$56-65$} & Sayı & 2 & 4 & 4 & 9 & 5 & 8 & 1 & 3 & - & - & 17 \\
\hline & & Yüzde & 3,8 & 7,5 & 7,5 & 17,0 & 9,4 & 15,1 & 1,9 & 5,7 & 0,00 & 0,00 & 32,1 \\
\hline & \multirow{2}{*}{65 üstü } & Sayı & 2 & 1 & 4 & 13 & 4 & 16 & 2 & 7 & - & - & 23 \\
\hline & & Yüzde & 2,8 & 1,4 & 5,6 & 18,1 & 5,6 & 22,2 & 2,8 & 9,7 & 0,00 & 0,00 & 31,9 \\
\hline & \multirow{2}{*}{ Toplam } & Sayı & 54 & 63 & 68 & 163 & 95 & 169 & 101 & 25 & 6 & 22 & 262 \\
\hline & & Yüzde & 5,3 & 6,1 & 6,6 & 15,9 & 9,2 & 16,4 & 9,8 & 2,4 & 0,6 & 2,2 & 25,5 \\
\hline \multirow{6}{*}{ 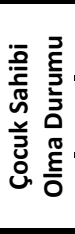 } & \multirow{2}{*}{ Var } & Sayı & 27 & 61 & 45 & 112 & 33 & 78 & 31 & 24 & 3 & 11 & 143 \\
\hline & & Yüzde & 4,8 & 10,7 & 7,9 & 19,7 & 5,8 & 13,7 & 5,5 & 4,2 & 0,50 & 1,9 & 25,2 \\
\hline & Yok & Sayı & 27 & 2 & 23 & 51 & 62 & 91 & 70 & 1 & 3 & 11 & 119 \\
\hline & YOK & Yüzde & 5,9 & 0,40 & 5,00 & 11,1 & 13,5 & 19,8 & 15,2 & 0,20 & 0,7 & 2,4 & 25,9 \\
\hline & Tonlam & Sayı & 54 & 63 & 68 & 163 & 95 & 169 & 101 & 25 & 6 & 22 & 262 \\
\hline & I oplam & Yüzde & 5,3 & 6,1 & 6,6 & 15,9 & 9,2 & 16,4 & 9,8 & 2,4 & 0,6 & 2,2 & 25,5 \\
\hline & illeolel & Sayı & 1 & 9 & 13 & 19 & 1 & 12 & 3 & 3 & - & - & 24 \\
\hline & IIKOKUI & Yüzde & 1,2 & 10,6 & 15,3 & 22,3 & 1,2 & 14,1 & 3,5 & 3,5 & 0,00 & 0,00 & 28,2 \\
\hline & Ortaokul & Sayı & 2 & 8 & 8 & 16 & 5 & 11 & 5 & 4 & - & 3 & 20 \\
\hline & 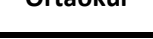 & Yüzde & 2,4 & 9,8 & 9,8 & 19,5 & 6,1 & 13,4 & 6,1 & 4,9 & 0,00 & 3,7 & 24,4 \\
\hline ह & lise & Sayı & 15 & 22 & 18 & 56 & 31 & 53 & 23 & 9 & 1 & 4 & 93 \\
\hline 产 & LISe & Yüzde & 4,6 & 6,8 & 5,5 & 17,2 & 9,5 & 16,3 & 7,1 & 2,8 & 0,30 & 1,2 & 28,6 \\
\hline$\varepsilon$ & Lisans & Sayı & 31 & 21 & 29 & 68 & 56 & 84 & 63 & 9 & 4 & 14 & 114 \\
\hline 滈 & Lisans & Yüzde & 6,3 & 4,3 & 5,9 & 13,8 & 11,3 & 17,0 & 12,8 & 1,8 & 0,80 & 2,8 & 23,1 \\
\hline & Lisans & Sayı & 5 & 3 & - & 4 & 2 & 9 & 7 & - & 1 & 1 & 11 \\
\hline & üstü & Yüzde & 11,6 & 7,0 & 0,00 & 9,3 & 4,7 & 20,9 & 16,3 & 0,00 & 2,3 & 2,3 & 25,6 \\
\hline & Tonlam & Sayı & 54 & 63 & 68 & 163 & 95 & 169 & 101 & 25 & 6 & 22 & 262 \\
\hline & loplam & Yüzde & 5,3 & 6,1 & 6,6 & 15,9 & 9,2 & 16,4 & 9,8 & 2,4 & 0,6 & 2,2 & 25,5 \\
\hline & Kamu & Sayı & 11 & 12 & 12 & 30 & 10 & 22 & 19 & 5 & - & 2 & 40 \\
\hline & çalışanı & Yüzde & 6,8 & 7,4 & 7,4 & 18,4 & 6,1 & 13,5 & 11,6 & 3,1 & 0,00 & 1,2 & 24,5 \\
\hline & Özel sektör & Sayı & 19 & 32 & 21 & 75 & 41 & 76 & 39 & 8 & 4 & 7 & 110 \\
\hline & uzer seкtor & Yüzde & 4,4 & 7,4 & 4,9 & 17,4 & 9,5 & 17,6 & 9,0 & 1,9 & 0,9 & 1,6 & 25,5 \\
\hline & Öğrenci & Sayı & 13 & - & 10 & 15 & 25 & 32 & 30 & - & 1 & 9 & 43 \\
\hline$\frac{10}{2}$ & & Yüzde & 7,3 & 0,00 & 5,6 & 8,4 & 14,0 & 18,0 & 16,8 & 0,00 & 0,60 & 5,1 & 24,1 \\
\hline 는 & Ev hanımı & Sayı & 3 & 13 & 13 & 16 & 1 & 7 & 2 & 3 & - & 2 & 20 \\
\hline 弟 & EV nanimI & Yüzde & 3,8 & 16,2 & 16,2 & 20,0 & 1,3 & 8,7 & 2,5 & 3,8 & 0,00 & 2,5 & 25,0 \\
\hline$\overline{\underline{y}}$ & Emekli & Sayı & 6 & 3 & 7 & 19 & 11 & 21 & 4 & 9 & - & - & 36 \\
\hline$\Sigma$ & гтиекі & Yüzde & 5,2 & 2,6 & 6,0 & 16,4 & 9,5 & 18,1 & 3,5 & 7,8 & 0,00 & 0,00 & 31,0 \\
\hline & Calismivor & Sayı & 2 & 3 & 5 & 8 & 7 & 11 & 7 & - & 1 & 2 & 13 \\
\hline & Çdişmİ & Yüzde & 3,4 & 5,1 & 8,5 & 13,5 & 11,9 & 18,6 & 11,9 & 0,00 & 1,7 & 3,4 & 22,0 \\
\hline & $n$ & Sayı & 54 & 63 & 68 & 163 & 95 & 169 & 101 & 25 & 6 & 22 & 262 \\
\hline & 10pidm & Yüzde & 5,3 & 6,1 & 6,6 & 15,9 & 9,2 & 16,4 & 9,8 & 2,4 & 0,6 & 2,2 & 25,5 \\
\hline
\end{tabular}




\section{Sonuç ve Öneriler}

Nüfus artışı ve kent alanlarına göç sebebiyle kentlerdeki yapı baskısı, gün geçtikçe artmaktadır. Bu duruma bağlı olarak kentsel alanlardaki açık ve yeşil alanlarının azalması da kaçınılmaz hale gelmiştir. Açık ve yeşil alanların azalması, kent insanı üzerinde fiziksel ve ruhsal olumsuzluklara yol açmaktadır. Bu nedenle insanların, ruhsal ve fiziksel olarak kendilerini yenileyebilecekleri ve kendilerine vakit ayırabilecekleri mekân arayışında olduğu görülmektedir. Kent parkları; kentlere fiziksel, iklimsel, çevresel katkı sağlarken; insanlar üzerinde sosyal, ruhsal ve kültürel katkılar sağlamaktadır. Kent parkları, birçok rekreasyonel olanakları içinde barındırmaktadır. Bu sebeple insanların ruhsal ve kültürel gereksinimlerini karşılaması açısından önem taşımaktadır.

Araştırma kapsamında kent parklarında bulunması öngörülen kullanım birimlerinin birçoğunun parkta mevcut olduğu tespit edilmiştir. Bilimsel ve eğitsel birimler başlığı altında belirlenen kullanım birimleri mevcut değildir. Ancak bu kullanım birimleri dışında eğitim kurumu olarak Antalya Büyükşehir Belediyesi Anaokulu bulunmaktadır. Aynı zamanda park sınırları içinde bir köpek parkı bulunmaktadır. Hayvan sahibi olan kent insanı için bir avantaj olan köpek birçok kullanıcı tarafından aktif olarak kullanıldığı gözlemlenmiştir.

Araştırma alanında; büyük çaplı problemler bulunmamakla beraber birtakım düzensizlik ve olumsuzluklar mevcuttur. Bunlara kullanıcıların sebep olduğu gözlemlenmiştir. Kullanıcılar tarafından park içerisine çeşitli atıkların bırakılması bu olumsuzlukların başında gelmektedir. Parktaki göller ve çevresi bakımsız halde görülmektedir. Göl kenarında bulunan motopomp ve dalgıç pompa kontrol rölesi, ziyaretçiler tarafından kolayca erişilebilir yerde bulunmaktadır. Bu çocuklar için sakıncalı bir durum arz etmektedir. Bu sorunun; motopomp ve dalgıç pompa kontrol rölesi tel bir kafes içerisine alınarak ve etrafını çeşitli yer örtücü veya kısa boylu çalılarla çevreleyerek giderilmesi mümkündür. Böylece ziyaretçilerin özellikle de çocukların erişimi engellenmiş olacaktır.

Park içinde bitki üretim yeri olarak bir fidanlık bulunmaktadır. Fakat bu bitki üretim alanının bakımsız olduğu görülmüştür. Bu da kullanıcılar üzerinde estetik açıdan olumsuz etki bırakmaktadır. Fidanlığın gerekli bakımları yapılarak bu olumsuz durum telafi edilmiş olacaktır. Fidanlıkta; ağaç ve çalı türlerinin yanı sıra, kentte yaşayan insanların evlerinde bakımını sağlayabilecekleri salon ve balkon bitkileri de yetiştirilmesinin, fidanlığın kullanımını arttıracağı öngörülmektedir. Aynı zamanda fidanlık içinde bitki marketi bulundurarak, park ziyaretçilerinin bitki ve bitki materyalleri gereksinimlerini karşılayacak, ekonomik açıdan da katkı sağlayacaktır.

Parkı tercih etme nedenleri arasında; kullanıcıların \%18,3 oranında görsel çekicilik ve estetiği göz önünde bulundurduğu görülmektedir. Aynı zamanda kullanıcıların \%17,6 oranla yaya gezinti alanlarını ve $\% 17,5$ oranla çay bahçeleri, kafe ve restoranları en çok kullandıkları alanlar olarak belirttikleri görülmektedir. Bunun yanı sıra kullanıcılar parkı $\% 25,5$ oran ile temiz hava almak ve stresten uzaklaşmak amacı ile kullanmaktadır.

Kullanıııların Atatürk Kültür Parkı'nda en çok kullandıkları alanlar; \%17,6 oran ile yaya gezinti alanları olduğu saptanmıştır. \%16,6 oranla kadın, \%18,7 oranla erkek kullanıcılar kullanmaktadır. \%26,8 oranla 65 yaş üstü kullanıcılar, \%24,4 oranla emekliler ve \%19,7 oranla ortaokul mezunu düzeyindeki kullanıcılar en çok kullandıkları alan olarak yaya gezinti alanlarını tercih etmişlerdir.

Kullanıcıların parkı kullanma amaçlarının \%25,5 oranla temiz hava almak ve stresten uzaklaşmak olduğu görülmüştür. \%23,3 oranla kadın, \%28,1 oranla erkek, \%32,1 oranla 56-65 yaş aralığında kullanıcıların, $\% 28,6$ oranla lise mezunu düzeyindeki kullanıcıların ve $\% 31,0$ oranla emeklilerin temiz hava almak ve stresten uzaklaşmak amacı ile parkı ziyaret ettikleri saptanmıştır.

Atatürk Kültür Parkı'nda gerçekleştirilen araştırmada elde edilen veriler ve analizler doğrultusunda, kent parklarında bulunması öngörülen kullanım birimleri park bünyesinde birçok kriteri karşıladığı görülmüştür. Buna bağlı olarak kullanıcıların parkı tercih etme nedenleri arasında; görsel çekicilik ve estetik, kullanım alanları arasında en çok yaya gezinti alanlarını ve temiz hava almak ve stresten uzaklaşmak amacı ile parkı kullanmaktadırlar. Elde edilen bu sonuç doğrultusunda kent yaşamının insanlar üzerindeki olumsuz etkilerini azaltmada, kent parklarının içerisinde barındırdıkları rekreasyonel hizmetlerinin önemini bir kez daha ortaya koyulmuştur. 


\section{Teşekkür ve Bilgi Notu}

Bu makale, Süleyman Demirel Üniversitesi F.B.E. Peyzaj Mimarlığı Anabilim Dalı'nda tamamlanan Yüksek Lisans tezinden üretilmiştir.

Makalede, ulusal ve uluslararası araştırma ve yayın etiğine uyulmuştur. Çalışmada Etik Kurul izni gerekmemiştir.

\section{Kaynaklar}

Eşkil Yüce, Ö. (2011). Engelliler İ̧̧in Dış Mekan Tasarım Özellikleri Bağlamında Ankara Kent Parklarının Irdelenmesi. (Yüksek Lisans Tezi), Bartın Üniversitesi, Fen Bilimleri Enstitüsü, Peyzaj Mimarlığı Anabilim Dalı, Bartın.

Google Earth. (2018). Google Earth Görüntüleme Erişim Adresi (24.04.2018): https://www.google.com.tr/intl/tr/earth/

Ibes Dorothy, C. (2016). Integrating Ecosystem Services Into Urban Park Planning \& Design. Cities and the Environment (CATE), 9(1), 1.

Jacobs, J. (1961). The Death and Life of Great American Cities. New York: Random House.

Kahya, C. (2018). Sakarya Kent Park ve Sakarya Park Örneklerinde Kullanıı Memnuniyeti ve Kalite Karşılaştırması. (Yüksek Lisans Tezi), Düzce Üniversitesi, Fen Bilimleri Enstitüsü, Peyzaj Mimarlığı Anabilim Dalı, Düzce.

Kılıç, A. N. (1997). Kent Parklarının Standartları ve Dağııışları. (Yüksek Lisans Tezi,) Ankara Üniversitesi, Fen Bilimleri Enstitüsü, Peyzaj Mimarlığı Anabilim Dalı, Ankara.

National Recreation and Parks Association, NRPA. (2012). Parks and Recreation in Underserved Areas: A Public Health Perspective. National Recreation and Parks Association, (NRPA). Available online at:http://www.nrpa.org/uploadedFiles/nrpa.org/Publications_and_Research/Research/Papers /Parks-Rec-Underserved-Areas.pdf

Özkan, B. ve Bayraktar, A. (1988). Akhisar Örneğinde Bir Kent Parkı Planlaması Üzerinde Araştırmalar. Ege Üniversitesi Ziraat Fakültesi Dergisi. Cilt: 25, No: 1, Bornova, İzmir.

Polat, A. T. (2001). Kent Parkı Kavramı ve Konya İçin Örnek Bir Çalışma. (Yüksek Lisans Tezi), Selçuk Üniversitesi, Fen Bilimleri Enstitüsü, Peyzaj Mimarlığı Anabilim Dalı, Konya.

Türkiye İstatistik Kurumu, TÜiK. (2019). TÜiK-Türkiye İstatistik Kurumu. Erişim Adresi (8.12.2019): http://tuik.gov.tr/UstMenu.do?metod=temelist

Uzun, G. (1987). Kentsel Rekreasyon Alan Planlaması. Çukurova Üniversitesi Ziraat Fakültesi Ders Kitabı. No: 48. Adana.

Yıldırım, C., Erdoğan R. ve Oktay, H. E. (2014). Antalya Kenti Parklarındaki Donatı Elemanlarının Değerlendirilmesi. Akdeniz Üniversitesi Ziraat Fakültesi Dergisi, Vol.27(1), 13-20. 